\title{
Evidence-based Environmental and Public Health Practices to Respond to the COVID-19 Crisis
}

\section{Morufu Olalekan Raimi ( $\sim$ ola07038053786@gmail.com )}

Niger Delta University https://orcid.org/0000-0001-5042-6729

\section{Aziba-anyam Gift Raimi}

Federal University Otuoke, Nigeria https://orcid.org/0000-0003-1683-415X

\section{Teddy Charles Adias}

Federal University Otuoke, Nigeria

\section{Systematic Review}

Keywords: Interprofessionalism, Living' reviews, Collective learning, Evidence-informed decision, COVID19 pandemic, Environmental policy process, Team-based care, Credibility/trust, Timeliness, Systems thinking, Nigeria

Posted Date: May 7th, 2021

DOI: https://doi.org/10.21203/rs.3.rs-504983/v1

License: (c) (1) This work is licensed under a Creative Commons Attribution 4.0 International License. Read Full License 


\section{Abstract}

Background: Given the unprecedented novel nature and scale of coronavirus and the global nature of this public health crisis, which upended many public/environmental research norms almost overnight. However, with further waves of the virus expected and more pandemics anticipated. The COVID-19 pandemic of 2020 opened our eyes to the ever-changing conditions and uncertainty that exists in our world today, particularly with regards to environmental and public health practices disruption.

Objectives: This paper explores environmental and public health evidence-based practices toward Responding to Covid-19.

Methods: A literature review tried to do a deep dive by using a variety of search engines including Research Gate, Google Scholar, Summon, PubMed, Scopus, Hinari, Dimension, CAB Abstract, OARE Abstract, Academia, Mendeley, SSRN search strategy to retrieve research publications, "grey literature" and expert working group reports.

Results: To achieve improved population health, more widespread adoption of evidence-based strategies is recommended, particularly in this uncertain time. As only together can evidence-informed decisionmaking (EIDM) can become a reality which include effective policies and practices, transparency and accountability of decisions, and equity outcomes; these are all more relevant in resource-constrained contexts, such as Nigeria. Effective and ethical EIDM though requires the production and use of highquality evidence that are timely, relevant and structured. One way to do so is through co-production. Coproduction (or co-creation or co-design) of environmental/public health evidence considered as a key tool for addressing complex global crises such as the high risk of severe COVID-19 in different nations.

Discussion: A significant evidence-based component of environmental/public health (EBEPH) consist of decisions making based on best accessible, evidence that is peer-reviewed; using data as well as systematic information systems; community engagement in policy making; conducting sound evaluation; do a thorough program-planning frameworks; as well as disseminating what is being learned. As researchers, scientists, statisticians, journal editors, practitioners, as well as decision makers strive to improve population health, having a natural tendency toward scrutinizing the scientific literature aimed at novel research findings serving as the foundation for intervention as well as prevention programs. The main inspiration behind conducting research ought to be toward stimulating and collaborating appropriately on public/environmental health action. Hence, there is need for a "Plan B" of effective behavioural, environmental, social and systems interventions (BESSI) to reduce transmission.

\section{Introduction}

For every complex problem, there is a solution that is simple, neat, and wrong. Hence, it is often necessary to make a decision on the basis of information sufficient for action but insufficient to satisfy the intellect. In this COVID-19 pandemic era where the public and the mass media attention is about serious health issues, it is important to explain why taking action should not be based on the basis of research study 
conducted individually, even though it remained prudently designed, effectively conducted, as well as appropriately interpreted and evaluated, which need to be highlighted. COVID-19 pandemic has been identified as a generation-defining, impacting economic shocks, families, communities and other unforeseen events in any country in the world, and has led to long-term economic financial conditions that have beset as well as create an "extinction-level event" which has cast an eerie shadow around the world long after the COVID-19 pandemic is behind us. Just over a year ago, news of a flu-like deadly virus affecting the central region of China began grabbing international headlines. It was the start of what would become a worldwide news event; one that would raise unique challenges for the environmental and public health practices and pose a series of lethal threats to environmental/public health. However, it is becoming increasingly clear that the threat is not only in the form of a deadly virus. The pandemic is also being used by malign forces as an opportunity to disrupt, unforeseen and unprecedented circumstances, to sabotage and even to prevent the free flow of trusted, independent information toward the impact of the COVID-19 pandemic, which present an acute case of reliability. The highly contagious COVID-19 pandemic has been weaponised to undermine freedom of expression and has provided a valid reason to usher in a range of reporting restrictions on a sliding scale of severity from limiting access to data, right through to punitive legislation and even life threatening [1, 2, 3]. Additionally, the relentless onslaught of misinformation and disinformation riddling social media platforms has created a real obstacle to COVID-19 truth-telling.

Indeed, COVID-19 vaccines offer much-needed protection from disease, but there has so far been no evidence of whether they also curb transmission. Recently, around the world, concern is growing about the impact the new, fast spreading SARS-CoV-2 variants will have on the pandemic. Most countries are facing a widespread variant of SARS-CoV-2 known as B.1.351 and B.1.1.7, which appears to somewhat decrease the efficacy of some vaccines and have raised growing concerns about the extent to which their mutations might help them evade current antibody treatments and highly effective vaccines. The news heightens concerns about B.1.351 and B.1.1.7, nonetheless researchers remain hopeful that the vaccine prevents severe disease and death. However, the chance of dying is around $35 \%$ higher for people who are confirmed to be infected with the new variant. Although, the data are preliminary, and it is not clear whether the variant is deadlier than previous strains or is spreading to more people who are vulnerable to severe disease. While it's possible some COVID-19 vaccines may offer less protection against some of these new variants, recent results have suggested the AstraZeneca vaccine may not provide much protection against the South African variant, there's still enough protection in most other current vaccines to prevent serious illness, hospitalization, and death. For now, emergence of these new variants should encourage all of us to take steps to slow the spread of SARS-CoV-2. That means following the three W's: Wear a mask, watch your distance, wash your hands often. It also means rolling up our sleeves to get vaccinated as soon as the opportunity arises. Hence, the global health, economic, and social events that rattled series of activities around the world in 2020 have kicked off a new, uncertain era of environmental/public health practices, and it may take a long time for such uncertainty to ease. As many environmental/public health experts are predicting that it could even outlast the pandemic itself. 
While the world remains alarmed to panic at the grip of the demonic novel COVID-19 infection, there is still plenty of bearish perception as 2020 will certainly and no doubt be etched in the minds of health-care professionals, including environmental health officers all over the globe for several years to come which is unprecedented in the modern health care setting $[4,5,6]$. While, the national response toward COVID-19 varies, from the swift and most proactive to haphazard and negligent to the worst. That nations have already managed the spread of the pandemic in a different way is expected, nonetheless COVID-19 pushes all health systems toward their limits, thereby revealing serious gaps in environmental/public health structure, even in countries that are acclaimed as the popular centers for readiness. Thus, the response toward COVID-19 shows a glaring lack of social health determinants as well as meaningful collective learning, community participation and engagement on important issues in a health emergency. The COVID-19 outbreak caused through severe acute respiratory syndrome coronavirus 2 (SARSCoV-2) has adversely affected social, economic events that rattled businesses as well as environmental health determinants and has challenged health professionals such as doctors, nurses, health workers, researchers, decision-makers and many others working in the health sector in many ways, while suspending the usual daily businesses [7].

COVID-19 pandemic has presented an acute case and also tested and assesses the national capacity of health systems toward withstanding health shocks while maintaining routine functions in many ways [8, $9,10]$. Hence routine reopening of service/activities toward approaching normalcy could continue for months or else years, but some positive results have been emerged and achieved in its wake. At the same time, global effort is being made to develop relevant international technologies, resources as well as available information that would create and accelerate data-driven results for all facets of this coronavirus pandemic. The coronavirus crisis is a global changing phenomenon and has become a top priority for our healthcare system, halting patient care processes which ranges from disrupting childhood vaccination as well as campaigns on polio eradication [11], maternal and child mortality are projected toward rising sharply, and health of young people to injuries, non-communicable diseases, as well as universal health coverage, despite unleashing enormous social, economic and health crises that threaten the world with antimicrobial resistance which threatens our ability to treat common infections, disrupting many research activities as well as overwhelmingly impacting medical education in various research activities. The coronavirus pandemic is not the first and foremost serious health challenge facing the world, nevertheless its long-term achievement will largely depend on rapid data synthesizing and information, appropriately and responsibly into comprehensive public and environmental health policies both national and international.

In the face of great uncertainty around Covid-19 pandemic future, epidemiologic models become an important planning tools for decision makers, clinicians as well as public health practitioners $[2,3,1]$. COVID-19 has made visible major global weaknesses, vulnerabilities and highlighted the necessity for health reforms towards promoting global access toward affordable care. At the same time, countries are examining their different policies towards protecting people at increased severe risk of disease. It may be the policies intended at preventing transmission in the general population, immunization (as the Oxford AstraZeneca vaccine and Pfizer BioNTech COVID vaccine has turn out to be available) because the world 
has received the Oxford AstraZeneca vaccine and Pfizer BioNTech COVID vaccine and has been roll-out to millions of people in the United States of America (USA), India, United Kingdom (UK), Ghana, Cote d'ivoire and Nigeria, also its distribution and immunization has commenced without political, religious or ethnic affiliation. Up until now, the seemingly bulletproof important priority is to rebuild and reenergize the country towards acting rather than reacting. As uncertainty around the peril of COVID-19 calamity grows continuously and geometrically, long-term protection policies need to be developed such as specific public safety measures towards protecting vulnerable populations at increased risk through reducing contacts between individuals in danger, etc. Recognizing that promoting sustainable development is risky, difficult and exhausting, particularly as the spread of SARS-CoV-2 pandemic increased geometrically, as those living in poverty which is leading to growing anger and frustration are currently at increased peril of setbacks with more than thirteen (13) million children out of school $[1,3,8,9,12]$. This stresses the importance of linking the results of environmental research with human health has mentioned. This necessitates understanding of the significance of interventions towards addressing system inequalities, universal health care as well as coverage issues, and wide-ranging public protection schemes as being part of response.

Now is the time toward realizing that we are not at equal peril of severe COVID-19 consequences and that there is need to work with stakeholders and development partners towards developing and improving effective response as well as solutions $[13,14,15,16,17,18,3]$. This paper offers research evidence to inform decision makers about people that could remain at increased peril or severe high risk of COVID-19 pandemic in diverse countries. Hence, scientific research evidence is required to investigate the environmental as well as public health practices in the coronavirus diseases era, which ought to place emphasis on diverse policies guidelines towards preventing those that are vulnerable and at increased risk. It is imperative toward comparing those individuals at high peril of severe COVID-19 pandemic toward helping nations to design as well as develop improved interventions measures toward protecting vulnerable populations as well as reducing straining on health complications as well as health systems $[3,18,9,2,1]$. These evidences can offer as well as advise a wide-ranging health assessment, social, as well as economic significances of protecting diverse groups $[15,16,17,19,20,8,21]$, highlighting the prerequisite toward developing and providing a long-term Covid-19 management policy as well as given the unprecedented scale of policy-makers', scientific evidence require large-scale partnership as well as collective learning in the scientific evidence synthesis community. Henceforth, outcomes improvement across countries can be attained through successful high-quality evidence certification that is properly implemented. To accomplish this, national systems, policies as well as political milieus require to be hospitable toward evidence informed methods, besides there is prerequisite toward fostering partnership, facilitate negotiation, promote as well as advance scientific evidence-informed decision-making (SEIDM) in Sub-Saharan Africa as well as the world at large toward achieving effective greater performance and worldwide sustainable implementation.

Since the 2019 coronavirus disease (COVID-19) has triggered seismic economic and societal changes which grapple with an uncertain future, that has consumed and changed our lives, the COVID-19 global crisis also revealed that the country is deteriorating in terms of environmental/public health readiness. As 
COVID-19 has become an imminent emerging, rapidly evolving situation of environmental/public health concern with 'threat multiplier to health in the 21 st century $[10,22,23]$. As confusion, disorientation, agitation and even psychosis have been associated with symptoms of COVID-19. The body of research is making the link among infection as a result of virus and neurological symptoms. The number of publicly reported deaths rate of the population due to the coronavirus disease 2019 (COVID-19) may underestimate the pandemic's death toll. These estimates are based on provisional data that are often incomplete and may rule out unreported deaths from COVID-19. In addition, the restrictions imposed by the pandemic (for example, stay-at-home orders, school closures, quarantine measures, personal hygiene, physical distancing measures used to contain the spread of the virus) may possibly claim lives indirectly through delayed care for acute emergencies, exacerbations of chronic diseases, and psychological distress (for instance, drug overdoses). As a result, the burden of severe acute respiratory syndrome coronavirus 2 (SARS-CoV-2) pandemic continues to rise, both due to morbidity and mortality from the pandemic itself and the impact of mitigation strategies [2, 3, 8, 9, 24]. Tailoring policies based on emerging evidence on the conditions associated with the severity of COVID-19 is essential to informing the actions of both decision-makers and individuals. This means moving from generalized populationbased mitigation strategies to focusing on people exposed to the risk of severe outcomes from COVID-19 $[15,16,17,19,20,21]$.

Too often, Jenicek [25] has repeatedly described evidence-based public health (EBPH) as "the conscientious, explicit, as well as judicious usage of available evidence in decisions making process towards communities care as well as populations in the realm of health maintenance and protection, disease prevention and development (health promotion)." Similarly, a concise definition emerged from Kohatsu [26]: "Evidence-based public health is the process of integrating science-based interventions with community preferences to improve populations health". While, public health has succeeded in solving numerous problems, but almost all successes have a double-edged sword. Programs as well as policies have remained enacted as well as, in most cases, results that are positive which shows an increase in the improvement number of population health. However, some people suffer from health disparities as well as social inequalities. This raises such questions like, is there a way to approach the lessons learned directly from successful interventions as well as applies them toward other topics and situations? Are we using evidence that is based on scientific research/evidence? How can we greatly foster political will towards supporting evidence-based policy making? How do we promote and influence incentives so that practitioners can make effective evidence usage? Just as evidence-based public health has become a topic of conversation for both practitioners and policymakers, it is so fundamental to our notion of justice, it is equally important for environmental/public health. Therefore, it should inform all of our decisions on how the intervention will be implemented, and in what populations, when and how to assess both the positive and sometimes negative impact of those interventions. Our commitment to justice also bears the responsibility of finding effective ways to reduce health disparities between groups existing in virtually all geopolitical units. For environmental and public health professionals, evidence is a type of data that includes epidemiologic (quantitative) data, program results or policy evaluations, and the qualitative data to be used in establishing judgments or decisions $[2,3,27,28]$ (see Fig. 1 below). Indeed, 
Brownson and colleagues identify a six-stage procedure through which practitioners are able to take a more evidence-based approach toward decision making, with the community members perspectives, fostering a more population-centered method, which appears to be a consensus that a combination of scientific evidence, as well as values, resources, and contexts, should enter into decision making. Hence, "Evidence-based public/environmental health is the process of integrating science-based interventions with community preferences toward improving populations health" or it involves "the available body of facts or information indicating whether a belief or proposition is true or valid." [2, 29].

Environmental/Public health evidence is often the result of a complex concepts of observation, theory, and experiment $[3,30]$. However, the value of evidence remains in the eye of the beholder (e.g., the value of evidence may differ from a stakeholder type) [2, 3, 31]. Medical evidence includes not only research, but also patient characteristics, patient's readiness to undergo a therapy, and society's values [32]. Decision-makers seek distributional consequences (i.e., who pays, how much and who benefits) [33, 34], and in practice, settings anecdotes sometimes provide detailed empirical data [2, 3, 35]. The evidence is typically imperfect and, as Muir Gray note [36], "The absence of excellent evidence does not make evidence-based decision making impossible; what is needed is the best available evidence, not the best evidence possible."

Most authors describe different types of scientific evidence for public health practice $[37,38]$ (see Table 1 below). Type 1 evidence identifies the causes of the diseases as well as the magnitude, severity, and preventability of risk factors associated with the diseases. They suggest that a specific disease or risk factor needs to be done. Type 2 evidence describes the relative effects of a particular interventions that cause or do not advance health, adding, "In particular, this must be done" [38]. It has been observed that adherence to regulatory guidelines of study designs can strengthen an "inverse (see Fig. 1 above) evidence law" through which interventions most likely to influence the public (e.g., policy change) are least valued in an evidence matrix emphasizing randomized designs [28, 39, 40, 41, 42, 43, 44]. A recent study showed a lack of research intervention (Type 2) compared to descriptive/epidemiologic research (Type 1). In a randomized controlled trial of tobacco use, alcohol use [45, 46, 47], and inadequate physical activity, the team found that in $2005-2006,14.9 \%$ of subjects reported an intervention, while, $78.5 \%$ of articles reported were descriptive or epidemiologic research. There is probable to be even less research published on Type 3 evidence showing how and under what contextual conditions interventions were implemented as well as how they were received, thus informing "how it should be done" [37]. So far, research has focused on internal validity (e.g., well-controlled efficacy trials) while giving sparse attention toward external validity (e.g., adaptation of scientific knowledge to a different context) $[2,3,48,49]$.

\section{Comprehending The Framework For Evidence}

Evidence of type 3 from an intervention context [37]. While many authors have written around the role of context it plays in providing information on the subject of evidence-based practice [31, 37, 105], there is not much consensus on its meaning. As we move from clinical interventions to population-level as well as policy interventions, context becomes more uncertain and unpredictable, variable, and complex. 
Definitions relevant to the context highlights information needed to adapt and implement an evidencebased intervention in a specific context or population [37]. The conditions for Type 3 evidence show five overlapping domains (see Table 2 below). First, there are the features of the target population for an intervention such as level of education and health history. This is the reason why interpersonal variables provide the most important context. For example, people with a history of cancer may be more susceptible to undergo cancer screening. Third, organizational variables must be taken into account. For example, if an agency succeeds in implementing a program in which evidence - based program is influenced through its capacity (e.g., agency leadership, a trained workforce) $[86,105]$. Fourth, it is known that social norms and cultural traits are closely linked to shape many health behaviors. Ultimately, the greatest political as well as economic forces will influence the context. For example, large-scale measures of certain disease can influence a state's political will toward addressing the problems in a logical and systematic way. Particularly for high-risk and understudied populations, there is an urgent need for evidence of contextual variables and ways toward adapting programs and policies across settings as well as population subgroups. Contextual COVID-19 pandemic questions are being addressed in the new "realist review," which is a systematic review process that not only examines whether the recent intervention is working effectively but also how interventions actually work in real-world settings [59].

\section{Challenges Related Toward Public/environmental Health Evidence}

Public/environmental health evidence has been described as underpopulated, dispersed, as well as varied. It is underpopulated because there are relatively few well-done evaluations of how the effects of public/environmental health interventions (Type 2 evidence) apply across varied cultural groups (Type 3 evidence). The criteria for public/environmental health decision making is also more dispersed than is evidence for clinical interventions. For example, evidence on the health impact of the built environment might be found in transportation planning. Finally, public/environmental health evidence is varied, in part since much of the science base for interventions is derived from nonrandomized designs or "natural experiments".

\section{Triangulating Evidence}

Triangulation involves combining multiple evidence from a variety of sources toward gaining insight into a specific topic as well as typically combines quantitative and qualitative data [38]. It often involves the use of several methods of data collection and/or analysis to determine points of commonality or disagreement. Triangulation are generally useful because of the complementary nature of information from varied sources. Although quantitative data provide an excellent opportunity to determine how variables are to made in the lives of many people, these data provide little in the way of understanding why such relationships exist. On the other hand, qualitative data, can help provide information to explain quantitative findings, or what has been called "illuminating meaning". There are many examples of the use of triangulation of qualitative as well as quantitative data toward evaluating health programs as well 
as policies, including AIDS \& HIV prevention programs [52], occupational health programs and policies [34], and chronic disease prevention programs in community settings [2, 99].

\section{Geographic And Cultural Differences}

The concept of EBPEH was developed largely by a Western, European American context [50]. The conceptual approach revealed in the reality from the epistemologic underpinnings of logical positivism, which finds meaning through rigorous observation and measurement. This is reflected in a professional preference among clinicians for research designs like the randomized controlled trial. Additionally, most research in the EBPEH literature are academic research, typically with external funding for wellestablished investigators. In contrast, in emerging countries and in some impoverished areas of developed countries, the evidence base for how best to address common public/environmental health glitches is generally limited even though the problem scope might be huge. Cavill and colleagues [51] likened evidence-based interventions across countries in Europe, showing that much of the evidence base in several areas is limited toward empirical observations. Even in more developed countries (such as United States), much of information published in peer-reviewed journals or data available by websites as well as official organizations might not sufficiently represent all populations of interest.

In environment and public health, there are four prime user groups for evidence namely: environmental and public health practitioners and their partners, who are likely to recognize the scope as well as quality of evidence in certain strategies (for example, policies, programs)? In actual fact, nevertheless, practitioners of environmental and public health often possess a comparatively narrow selection process option. Funds resulting from local, state and federal sources are usually earmarked for definite purpose [e.g., surveillance as well as sexually transmitted diseases treatment [52], retail food establishments inspection [53,54]. However, there is an opportunity for environmental and public health professionals, including the obligation, to carefully examine the evidence to find alternative ways to achieve required health goals $[3,14,34,55,56]$. The next generation user group consists of decision-makers at local, regional, state, national, and international levels (deciding at the macro level how to allocate public resources for which they have been elected stewards $[2,15,16,17,19,20,21,57]$. This group has additional responsibility for formulating policies for complex and controversial public issues), Stakeholders (This group consist of many development partners i.e. nongovernment organizations whose missions focus on or incorporate health improvement, directly or through improving the social and physical milieus that are key population health determinants for example whether the community water supply should be fluoridated, dumpsite should be sited in a community cemetery or burial ground) and researchers on population health issues (They develop and use evidence to explore research hypotheses. Some are primarily interested in the methods used to determine the quality and implications of research on population-based interventions). Both enhance and use the evidence to answer research questions. However, the additional increased benefits of evidence-based environmental/public health (EBE/PH) have many indirect as well as direct benefits, including access toward a more as well as better quality evidence toward improving public's/environmental health, an effective and efficient probability of successful 
policies as well as programs implemented, better workforce productivity, as well as greater efficient usage of private as well as public resources $[9,58]$.

Therefore, decisions about when to intervene and what program or policy to implement are not simple and straightforward in most areas of environmental, public health and clinical practice. These decisions are generally based on three fundamental questions: (1) Should environmental/public health action be taken to address a particular environmental/public health issue (Type 1, etiologic evidence or evidence of behavioral knowledge)? (2) What measures or action must be taken (Type 2, intervention evidence or proof of intervention)? (3) How can a particular program or policy most effectively be implemented at the local setting (Type 3, contextual evidence)? Table 1 presents a range of scientific evidence for environmental/public health practice $[2,37,58]$. Type 1 evidence assesses the causes of the diseases and its magnitude, severity, and preventability of risk factors and diseases. Type 2 evidence describes the relative effects of specific interventions that may or may not improve health. Type 3 evidence comes from the context of the intervention and specifies the five overlapping domains (Table 2).

Table 1

Comparison of the Types of Scientific Evidence

\begin{tabular}{|c|c|c|c|c|}
\hline$S / N$ & Characteristic & Type 1 & Type 2 & Type 3 \\
\hline 1 & $\begin{array}{l}\text { Typical } \\
\text { data/relationship }\end{array}$ & $\begin{array}{l}\text { Size and strength of } \\
\text { preventable risk- } \\
\text { disease relationship } \\
\text { (measures of burden, } \\
\text { etiologic research) }\end{array}$ & $\begin{array}{l}\text { Relative } \\
\text { effectiveness of } \\
\text { public health } \\
\text { intervention }\end{array}$ & $\begin{array}{l}\text { Information on the } \\
\text { adaptation and translation } \\
\text { of an effective intervention }\end{array}$ \\
\hline 2. & Common setting & $\begin{array}{l}\text { Clinic or controlled } \\
\text { community setting }\end{array}$ & $\begin{array}{l}\text { Socially intact } \\
\text { groups or } \\
\text { community-wide }\end{array}$ & $\begin{array}{l}\text { Socially intact groups or } \\
\text { community-wide }\end{array}$ \\
\hline 3. & Example & $\begin{array}{l}\text { Smoking results in } \\
\text { lung cancer. }\end{array}$ & $\begin{array}{l}\text { Price upsurges } \\
\text { from a targeted } \\
\text { media campaign } \\
\text { decrease the } \\
\text { rates of } \\
\text { smoking. }\end{array}$ & $\begin{array}{l}\text { Comprehending the } \\
\text { political problems of } \\
\text { increase in price or aiming } \\
\text { at media messages toward } \\
\text { specific audience segments }\end{array}$ \\
\hline 4. & Quantity & More & Less & Less \\
\hline 5. & Action & $\begin{array}{l}\text { Something must be } \\
\text { done. }\end{array}$ & $\begin{array}{l}\text { These specific } \\
\text { priorities must } \\
\text { be implemented. }\end{array}$ & $\begin{array}{l}\text { How can this intervention } \\
\text { be implemented }\end{array}$ \\
\hline
\end{tabular}


Table 2

Contextual Variables for Intervention Design, Implementation, and Adaptation

\begin{tabular}{|c|c|}
\hline Category & Examples \\
\hline \multirow[t]{3}{*}{ Individual } & Personal/Individual health history \\
\hline & Education level \\
\hline & Basic human needs ${ }^{a}$ \\
\hline \multirow[t]{3}{*}{ Interpersonal } & History of family health \\
\hline & Social capital \\
\hline & Peers support \\
\hline \multirow[t]{4}{*}{ Organizational } & Organizational culture \\
\hline & Staff expertise \\
\hline & Staff configuration \\
\hline & Physical infrastructure \\
\hline \multirow[t]{4}{*}{ Sociocultural } & Values \\
\hline & Social norms \\
\hline & History \\
\hline & Cultural traditions \\
\hline \multirow[t]{3}{*}{ Economic and political } & Political ideology \\
\hline & Political will \\
\hline & Lobbying as well as special interests costs and benefits \\
\hline
\end{tabular}

\section{Source}

Adapted from Brownson et al., [38] and Raimi et al., [2]

Firstly, there are features of the number of populations for intervention like, for instance education level as well as health history. In addition, interpersonal variables make available an important context. For instance, an individual with cancer family history might be more probable toward undergoing cancer screening. Third, institutional variables ought to be considered. For instance, whether an organization is successfully implementing an evidence-based program that may be influenced through the aforementioned capacity (e.g., professional workforce, organizational leadership) $[58,7,2,1]$. 
Fourth, it is argued that social norms and cultural norms cause and shape a lot of health behaviors. Finally, more political and economic forces affect context. For instance, the occurrence of high rate for a certain disease like the recent COVID-19 pandemic, has claimed far too many lives worldwide. Fortunately, as environmental health officers and doctors continue to gained more experience at monitoring, contact tracing, communicating and treating COVID-19 patients, and many people hospitalized eventually recover, this may influence a state's political will to address the issue in a meaningful, logical and systematic way $[8,18,9,3,2,1]$. Particularly because of the understudied populations at high-risk, there is a great need for more evidence between contextual variables as well as process toward adapting program change as well as policies in context as well as population subgroups. Problem-solving questions are addressed in novel detail known as "realist review," which remains a systematic assessment process that explores not only how intervention works, but then again how interventions measures work in a real-world situation $[1,2,3,59,60,61]$. Numerous ideas are important in achieving a greater evidence-based method toward the practice of public and environmental health. Essentially, scientific knowledge is required on programs as well as policies that can be effective towards promoting and improving health (i.e., conducting evaluation research toward generating sound evidence) $[58,62,2,3]$.

Second, to translate science into practice that is scientifically sound, there is need to marry information on evidence-based interventions from the peer-reviewed literature with the realities of a specific real-world milieu $[58,2,3]$. To achieve this, there is need to better define decision making processes that must be evidence-based. Finally, wide-scale dissemination of interventions of proven effectiveness must occur more consistently at state and local levels $[63,34,3,3]$. Therefore, the main characteristics of evidencebased features of environmental/public health decision making comprise:

\section{Decision-making based on the best available peer-reviewed evidence (both quantitative and} qualitative research): A starting point is the scientific literature and guidelines developed by expert panels advice. Additionally, preliminary findings from researchers and practitioners are often presented at regional, national, and international professional conferences.

2. Systematically using data and information systems: Data are being developed more for local level issues and a few early efforts are under way to improve the environmental/public health policy surveillance systems. For instance, a group of federal and voluntary agencies have recently developed policy surveillance systems for tobacco, alcohol, and, more recently, school-based nutrition and physical education $[45,46,47]$.

3. Developing and application of robust program planning frameworks (which is often rooted in behavioral science theory): For instance, ecological models or systems are progressively used where "appropriate cultural changes take place in the social milieu brings about individual's changes, and support population considered critical to the implementation of changes in the environment" $[10,55$, $56,57,60,61,64,65,66]$. These models emphasize the need toward solving remarkable multiple levels problems as well as emphasize the interaction as well as integration of elements within and between interpersonal, individual, organizational, community and governmental levels. The aim is toward creating a healthy positive community milieu that offers information that enhances health- 
promotion as well as social support toward helping the population live healthier and better lifestyles. Interventions that are effective are most frequently grounded on the principles of health-behavior theory [30].

4. Community assessment involvement and decision-making: Community-based methods include research community members as well as projects intervention and demonstrates progress made towards improving public health as well as addressing disparities in health. Academicians, practitioners, as well as members of the community who collaboratively highlight key concern issues, develop intervention strategies, as well as evaluate outcomes. This method builds on data from "stakeholder" input [67, 2, 3], builds on existing resources, facilitates collaboration between all parties, and integrates knowledge and action that seek to lead to a fair distribution of the benefits of an intervention for all partners.

5. Conducting sound and appropriate evaluation: In most cases in population health, programs as well as policies are implemented without fully focusing on methodical evaluation. Additionally, even if the programs are not effective, sometimes, they are sustained due to political or historical reasons. Evaluation criteria should be based on the development of early program as well as had better consist of both formative as well as outcome evaluation. For instance, the injury program management was properly discontinued after evaluating its effectiveness. This evaluation of the program demonstrates the usage of both multiple critical quantitative as well as qualitative data towards framing the evaluation model.

6. Disseminating what is being taught to key stakeholders in decision-makers: If a program or policy is implemented, or if final results is known, other public health such as community medicine, social medicine, community health and preventive medicine (environmental health) can draw on their research findings to enhance their own use of evidence, while making decision. It can be disseminated or communicated to health practitioners through scientific literature, toward overall public through the media, toward decision-makers through individual meetings, as well as toward public/environmental health professionals through training. Effective interventions are required in many settings, comprising worksites, health care settings, schools, as well as wide-ranging community environments etc. Hence, accomplishing these activities in EBE/PH is likely to require a synthesis of scientific skills, enhanced communication, common sense, and political acumen.

\section{Systematic Techniques And Methods To Enhance Environmental/public Health Evidence-based Uptake}

Several tools as well as planning methods can help environmental/public health practitioners in answering questions like: What are the magnitude of the environmental/public health challenges relating to COVID-19 pandemic; If there is an effective priorities aimed at resolving the challenges; What about the local environmental information as well as specific intervention that is useful in determining its possible use in relation to the current state of affairs at hand (Covid-19 pandemic); Is it that a specific program is worth doing or policy worth having (i.e., is it better than having substitutes), as well as will it yield suitable investment return, measured in terms of monetary or health consequences? These tools include: 


\section{Public/environmental Health Surveillance}

According to the public/environmental health adage, which state that "what gets measured, gets done." This measurement often begins with public/environmental health surveillance, the ongoing systematic collection, analysis, interpretation, and dissemination of COVID-19 pandemic health data for the purpose of preventing and controlling disease, injury, and other health problems. Public/environmental health surveillance is an important instrument for those using EBEPH. It includes building a systematic analysis, collection as well as routinely interpreting detailed health information/data, and combining the strengths and weaknesses of disseminating data over time towards those accountable for prevention as well as disease control or injury [3]. Environmental/Public health surveillance systems should have the capacity to collect and analyze data, disseminate data to public health programs, and regularly evaluate the effectiveness of the use of the disseminated data $[2,3,68]$. For example, the ongoing documentation of the prevalence of COVID-19 pandemic as a justification for eliminating COVID-19 spread and for documenting the effects of these actions $[2,3,9,18]$. In substance use control in the Niger Delta region of Nigeria, a common agreement metric for substance use across Bayelsa states was recognized [45, 46, 47]. While, systems of surveillance are supported at local, state and federal levels and could be used toward determining the diseases frequency as well as other conditions of health in a defined population. At minimum, five main objectives of the surveillance systems could be stated: (1) health assessment and monitoring status as well as general health risks; (2) to provide a disease-specific understanding of events as well as trends; (3) planning, implementation, monitoring, as well as appraising health policies and programs; (4) put in place financial management as well as information monitoring; and (5) conduct research in environmental/public health $[1,2,3]$. Some systems of surveillance presently existing can now offer deaths, births, birth defects, cancers, infectious diseases as well as health behaviors information. Individual system frequently has enough information toward assessing the prevalence or incidence rates as well as toward describing diseases frequency or condition of health through a person, place, as well as time. Even the surveillance systems data could be used toward obtaining a baseline as well as follow-up measurements aimed at specific populations.

\section{Systematic Reviews And Evidence-based Processes}

Systematic reviews involve comprehensive syntheses of collections of databases on specific topic. Good review reading may remain one of the utmost resourceful ways toward getting acquainted with advanced research as well as practice on several precise environmental/public health topics $[69,70]$. The use of explicit, systematic methods (i.e., decision rules) in reviews limits bias and reduces chance effects, thus providing more reliable results on which to make decisions [71]. One of the utmost important critiques for public/environmental interventions in health is the "Guide toward Community Preventive Practices" (the Community Guide), providing a synopsis of contemporary scientific literature using a well-defined and rigorous approach where existing important research are units of analytical analysis [72, 73]. The Public Guide offers to addressed (1) What interventions statements are been considered or evaluated as well as what are their implications? (2) What interventions aspects could support clients in choosing between 
proven interventions set that are effective? (3) How much does this intervention cost, as well as how much does it costs in relation to probable impacts on health? A respectable systematic critique should enable professionals to comprehend local contextual situations required for fruitful implementation [74].

\section{Economic Evaluation}

Economic evaluation is the comparison of costs and benefits to determine the most efficient allocation of scarce resources. We undertake economic evaluations all the time in everyday life, although we seldom think of the process explicitly. It is an important component of evidence-based practice [75]. It could make available evidence toward evaluating the absolute alternative value of expenditures provided to the public/environmental health programs as well as policies. In cost-benefit analysis, all decision options based on costs as well as consequences remain valued in economic terms. Most frequently, placement on financial investment is related to an intervention likened to its effects on health, for instance, disease cases prevented or saved years of life. This method on cost-effectiveness analysis (CEA), may show the absolute value of some alternative interventions (i.e., return on health on euro/dollars invested) [75]. Costeffectiveness analysis (CEA) has become an increasingly important tool for researchers, practitioners, and policy makers. However, relevant data to support this type of analysis are not always available, especially for possible public policies designed to improve health $[35,76,3]$. While, there are four interrelated types of economic evaluation namely: cost-benefit analysis (CBA), cost-effectiveness analysis (CEA), cost utility analysis (CUA), and cost-minimization analysis (CMA). The four techniques vary chiefly in the mode of how benefits are measured. The cost-benefit analysis (CBA) measures the benefit in economic units (e.g., euros, dollars), while the cost-effectiveness analysis (CEA) measures the benefits in the relevant health unit (e.g., saved lives). Cost utility analysis (CUA) is a form of costeffectiveness analysis (CEA) in which the benefits (such as life expectancy) are adjusted for life quality as well as quantified through a measure of health utility (typically quality-adjusted life years [QALYs]). Cost-minimization analysis (CMA) remain used once the two benefits interventions are the same, so the benefits measurement remains not a problem. Since cost-benefit analysis (CBA) uses the utmost "generic" outcome measure (several factors could remain measured through currency, together with the value of public health projects as well as educational interventions), it enables for a comparison of multiple programs. Its outcomes (see Fig. 2 below) shows the potential outcomes of an economic evaluation [2]. In view of the four (4) squares of the graph. Programs toward improving health as well as saving money (Quadrant IV) are certainly valuable as well as ought to be implemented. Likewise, programs that undermine health as well as costs affordability (Quadrant II) are unwelcome as well as must not remain continued or initiated. The two quadrants remaining (I and III) are in critical condition as well as where monetary appraisal can be more informative. In history, systems of environmental/public health as well as nations develop, interventions as well as programs began in Quadrant IV, through these programs that remain cost saving as well as improve and maintain health. Several initial public/environmental health interventions, like systems of sanitation, drop in Quadrant IV. When interventions are used as well as implemented, attention turns to programs in Quadrant I that improve and maintain health at an affordable cost. After all, as pressures in budgetary activities rise, programs in 
quadrant III are bear in mind: programs that lessen costs, nevertheless add loss toward health status. Aiming at the four (4) quadrants, the key question is, what is investment return (or disinvestment) towards public's funds? Economic evaluation offers a means toward answering this pertinent question, so programs can be selected for the highest investment return.

Using the above conceptual framework (figure 2 above) for the case of COVID-19 pandemic, numerous important conceptual economic evaluation elements can remain recognized. Before bearing in mind the procedure of conducting economic evaluation, it can be helpful toward determining the overall elements as well as all economic evaluations approach. The primary step is toward choosing the economic evaluation opinion. Each intervention could be thought of in several ways, often categorized as going from narrow toward broad. Health agencies or organization opinion should directly take part in delivering projected intervention. The next step which may be the insurers opinion, or payers, particularly in the health care industry, where consumers as well as payers remain two (2) distinct groups. The widest opinion is that of the whole society. Recommendations has been based on this wide-ranging economic evaluation opinion for all, as well as it is obligatory in quite a few countries having an established national health system. The viewpoint of the society is importantly suitable in public/environmental health as it seeks interventions designed toward benefiting taxpayers as well as the public funding the costs.

\section{Health Impact Assessment}

Health impact assessment (HIA) is a forward-looking, evidence-based tool used to inform stakeholders and policymakers about the potential health impacts of proposed projects and policies and to identify options for maximizing potential health benefits and minimizing potential harm. Similarly, Health Impact Assessment (HIA), which is a blend of several methodologies in the assessment of the possible health impact on a population and its distribution, arising from policies, programmes, or projects is instrumental in linking with other sectors to deal with the root cause of health challenges and thereby fostering the successful actualization of the sustainable development goals, having sprung into prominence in the last few decades $[15,16,17,19,20,21,57]$. Health impact assessment (HIA) is a relatively new method that seeks to estimate the probable impact of a policy or intervention in non-health sectors, such as agriculture, transportation, and economic development, on the health of the population $[2,6,21,28,41$, $42,43,44,57,77]$. Other HIAs is aimed to ensure the participation of the actors involved in the development of a particular project. This latter method, which forms the foundation of the environmental impact assessment that several massive place-based projects is obligatory through law, which is comparable toward the nonregulatory method that has remained accepted for other HIAs. In general, HIA, in all its procedures, has remained acceptable by way of a tool due to the growing evidence that the social as well as physical milieus remain a significant health determinant as well as health inequalities in populations (see Fig. 3 below). Hence, social determinant of health (SDoH) could be influenced by policies and programs, and are associated with better health outcomes. Social Determinant of Health (SDoH) is strongly influenced through policies, systems, as well as the environments (PSE). Diagram in Fig. 3 used by County Based Health Rankings as well as Roadmaps recognize the interplay among health 
outcomes, the Social Determinant of Health $(\mathrm{SDoH})$, are policies as well as programs. For instance, tobacco being a foremost health outcomes determinant (e.g., quality of life, mortality), as well as the reduction in the use of tobacco and is strongly influenced through cigarettes prices as well as environmental determinism in the community that are smoke-free using cessation clinics availability.

It is now being used to help assess the potential effects of many policies and programs on health status and outcomes $[15,16,17,19,20]$. HIA is a systematic process for identifying and communicating the potential health-related impacts of proposed projects and policies and formulating recommendations to maximize potential health benefits and minimize potential harm $[15,17]$. It combines several multidisciplinary approaches in the assessment of health-related consequences that may arise from a project, policy, and programme that does not clearly define health as is major focus, based of evidences of health effects from a well-structured framework. HIAs application spans over its use in a wide range of situations, such as the appraisal of national policies, infrastructural development, transportation and national/regional agricultural projects. Public participation and interagency synergy are two key positive outcomes; however, the setback is that there are no globally accepted methods in the evidence-based health impacts. Despite being a promising emerging practice, it has proven to be a great tool in the understanding of possible human health consequences, thereby informing decision-making and public policies $[15,16,20]$.

\section{Participatory Approaches}

Participatory approaches that actively involve community members in research and intervention projects show promise in engaging communities in $\mathrm{EBE} / \mathrm{PH}[2,26,79]$. Practitioners, academicians, and community members collaboratively define issues of concern, develop strategies for intervention, and evaluate the outcomes. This approach relies on "stakeholder" input $[3,67]$, builds on existing resources, facilitates collaboration among all parties, and integrates knowledge and action that, it is hoped, will lead to a fair distribution of the benefits of an intervention or project for all partners [13, 80]. Stakeholders, or key players, are individuals or agencies that have a vested interest in the issue at hand $[13,81]$. In the development of health policies, for example, policy makers are especially important stakeholders [82]. Stakeholders should include those who would potentially receive, use, and benefit from the program or policy being considered. The three (3) stakeholders' groups are pertinent viz: people affected through interventions, people developing programs as well as those who used the program evaluations results. The three groups of people involved include: the creators of the program, those who participated in the program and those who used the results of the program. Participatory methods can also be an existing challenge in following EBEPH guidelines, particularly in attainment of appropriate agreement through which appropriate methods are used aimed at addressing a specific health problem i.e., Covid-19 pandemic $[1,2,3,8,9,18,83]$.

\section{An Approach Toward Increasing Evidence Use In The Practice Of Environmental/public Health}

Page $17 / 47$ 
Education as well as training backgrounds are needed to improve and strengthen EBEPH proficiencies workforce. The prominence on EBEPH principles is not taught in the same way in all the subjects represented by public/environmental health professionals. For instance, a public/environmental health professional may not be sufficiently trained to pinpoint the most recent evidence as well as interpret other possibility than what an epidemiologist can do. A newly health educator graduate having a master's degree in public/environmental health is expected to have an expanded understanding of the significance of EBEPH better than a specialist in environmental health with a bachelor's degree. Perhaps less than half of environmental/public health practitioners have little prescribed training or education in the discipline of environmental/public health like health education, environmental health ethics and epidemiology $[4,5$, 84]. Most of these specialists receive formal regular graduate education or training in a college of health sciences or other programs in public health. Presently, it seems that limited public/environmental health departments need more ongoing education and training around mandatory EBEPH. Although the recognized EBEPH concept is relatively novel, but not fundamental skills. For instance, evaluating a program intervention through reviewing scientific literature aimed at evidence are skills frequently taught in postgraduate programs in environmental/public health or other areas of academic disciplines, as well as they are the basis for the practice of public/environmental health. While, the most frequently EBEPH applied outline is perhaps that identified by Brownson and colleagues (Fig. 4 below), which tends to use a seven-stage procedure $[58,85,86]$. The process used in applying this framework is nonlinear and entails numerous iterations $[2,86,87]$. Competencies for more effective environmental/public health practice are becoming clearer $[1,2,3,88,89]$. For example, to carry out the EBEPH process, the skills needed to make evidence-based decisions require a specific set of competencies [90] (see Table 4 below). To address these and similar competencies, EBEPH training programs have been developed in the developed countries for public health professionals in their various state health agencies $[2,3,86,91]$, local health departments, and community-based organizations [2, 3, 92, 93], and similar programs have been developed in other countries [87, 90]. Some programs show evidence of effectiveness $[86,93]$. The most common format uses didactic sessions, computer labs, and scenario-based exercises, taught by a faculty team with expertise in EBEPH. The reach of these training programs can be increased by emphasizing a train-the-trainer approach [87, 90]. Other formats have been used, including Internet-based self-study [92, 94], CD-ROMs, [90] distance as well as distributed networks learning, and technical assistance that are targeted. Educational training programs can be very effective in delivering "change agents" who are seen as professionals, but also share general goals as well as characteristics through the trainees [95]. A leadership and staff commitment aimed at life-long learning are also key ingredient toward training successes [96]. Training implementation toward addressing EBEPH competencies must be in accordance with the principles of adult education and learning. These occurred problems remained recently articulated with Bryan and colleagues [97], who highlighted the need to (1) know why the audience is learning; (2) tap into an underlying motivation to learn by the need to solve problems; (3) respect and build on previous experience; (4) design learning methods that match the development background as well as recipient's diversity; and (5) actively participating with the participants in the education/learning process. Below are a sequential framework seven-stage steps, toward promoting better evidence use in everyday policy making (see Fig. 4 below). It is remarkable to remember that this procedure is rarely a 
stringently linear or prescriptive one, nonetheless it must include several feedback "loops" as well as common processes that exist in multiple models' program-planning.

\section{Community Assessment}

Community (or needs) assessment is "a systematic set of procedures undertaken for the purpose of setting priorities and making decisions about program or organizational improvement and allocation of resources. The priorities are based on identified needs." [98] A community assessment may involve a variety of different data types, including epidemiologic (quantitative) data, qualitative information, data on health inequalities, and patterns of health resource utilization. The first part of community assessment is very important in identifying a problem or an issue. A community assessment typically could begin through looking at baseline sources or background information about health issues in a community. These may comprise primary and/or secondary data sources. Primary data encompass novel collection of information on specific programs or study through using techniques like a community examination, focus groups and interviews, etc. While, the community may be defined as individuals who live within a specified geographic region or as individuals who have a common experience or share a particular social or cultural sense of identity [91]. In conducting the assessment, it is also important to identify any subgroups within the community of interest (e.g., youth, lower-income adults) so that the assessments can adequately reflect the range of community members. Hence, community assessments may include efforts to identify morbidity and mortality, environmental and organizational conditions, existing policies, and relationships among key stakeholders. Community assessments identify the health concerns in a community, the factors in the community that influence health (i.e., determinants of health), and the assets, resources, and challenges that influence these factors [98]. Ideally, assessment is a process in which community stakeholders including community members and a broad array of community-based and government organizations become partners in assessing the community and moving from assessment to action planning. While, community assessments remain critical toward ensuring appropriate priorities are been carried out. This is for the reason that they can make available an understanding of the importance of the community setting so that priorities stay planned, designed as well as implementing ways to leverage as well as maximizing the community benefit. Additionally, the assessments can be recognized (as well as in some cases improve) support aimed at specific priorities' methods. This significant support is garnering resources as well as safeguarding an intervention that is successful. Assessments can likewise be an important baseline measure for a series of circumstances. Hence, assessing community characteristically arises before program development or policy as well as seeks toward comprehending the public/environmental health challenges as well as interventions in a specified community. It likewise begins toward recognizing recent resources previously in place toward addressing this apprehension. Data is occasionally obtained from national as well as local data sets in addition to surveillance systems. Another useful information at this level is a written contextual documentation, or setting, within which the problem of health is happening, together with social assessment, economic, as well as physical conditions. Data for assessing community may be collected with qualitative (e.g., individual or group interviews) or quantitative (e.g., questionnaires) methods. The 
decision concerning what to look for need to remain guided through the assessment goal. For example, a youth-focused assessment may include factors other than age assessment. For example, an adolescence focused assessment may comprise diverse elements other than focusing on adult's assessment who are older. Bearing in mind, there remain likewise some useful general guiding principle to consider when engaged in assessment planning. It is remarkable toward assessing factors in particular along the full ecologic series of factors influencing the health of population as well as well-being, in doing so, including the community assets, besides not just the challenges.

Ecologic frameworks suggest that individual, social, and contextual factors influence individual behavior change and health [92]. Several variations of an ecologic framework have been proposed [99]. Based on work conducted, it is useful to consider assessment of factors at five levels:

1. Individual factors: characteristics of the individual such as knowledge, attitudes, skills, and a person's developmental history

2. Interpersonal factors: social networks of formal as well as informal, including social support systems such as friends and family.

3. Organizational factors: organizational features, social institutions, as well as operational rules or regulations. organizational factors assessments might not only include the institutional existence nevertheless change readiness as well as organizational capacity (e.g., organizational support, communication within and amongst policy making structures, organizations, leadership as well as availability of resources [91].

4. Community factors: associations amongst economic forces, organizations, the physical milieu, as well as cultural changes that could shape people behavior

5. Government and policy issues: national, state and local laws, rules, as well as regulations

The use of the ecologic framework makes it possible to assess indigenous community people (their health as well as wellness and people's behaviors), the agencies as well as the organizations serving the community, and the milieu within which members of the community reside $[34,100]$. In detail, the greatest effective priorities act at multiple levels because societies are people who communicate with each other on different social networks within a specific context; thus, need assessment should help to understand this extensive variety of factors in general. Hence, Table 3 shows a number of probable ecologic framework indicators aimed at each of these stages. 
Table 3

Characteristics of Effective Community Coalitions

\section{$\mathrm{S} / \mathrm{N}$ Characteristic Description}

1. Holistic and comprehensive

2. Flexible and responsive

3. Build a sense of community

4. Build as well as improve resident engagement in community life

5. Offer a vehicle for empowering community
Collaborate to resolve problems deemed important; A good example is the Ottawa Charter for promoting health.

Coalitions to answer emerging problems as well as adapt its strategies to meet the new needs of the community.

Members regularly express and report that they value as well as obtain professional and personal support for their participation in collaborative relationships.

Make available a structure for renewed civic engagement; Collaborate as a forum where multiple sectors can engage together.

When community coalitions address indigenous issues, it often develops social capital, permitting residents toward having an impact on multiple problems.

6. Permit diversity to be valued as well as celebrated

When communities become more diverse, integration offers a vehicle to bring together diverse group toward solving common challenges.

7. Incubators for innovative solutions toward large challenges

Solving problem happens not only at local levels, but also at regional as well as national levels; local leaders may become national/global leaders.

Source: Adapted from Wolff, [101]

\section{Developing An Initial Statement Of The Issue}

Professionals must start with developing a brief description of the problem or issue being considered. In order to receive support on any issue (by the organization, a funding agency or decision makers), the issue should remain evidently articulated. This part of the problem definition corresponds to the initial stages of the strategic program planning process, which typically includes a description of the internal strengths as well as weaknesses, mission, threats and external opportunities as well as future vision. This typically helps define the gaps amongst the program current status or organization as well as the goals desired. The main mechanisms in statement issue comprise the condition of health or perceived risk factor, number of affected population(s), the size and the problem scope, potential stakeholders as well as prevention opportunities.

\section{Quantifying The Issue}

Once important information about a public health problem has been established, it is often helpful to identify the root sources of the prevailing data. Just as such data might depend on recent vital statistical data (records of death/birth), special surveys, surveillance systems or other national studies. In 
public/environmental health, qualitative studies could take many forms. the utmost popular descriptive type of study consists of scientifically effective sample survey of the people of interest (a representative cross section). This type of cross-sectional studies was not designed toward changing health status (like an intervention) but then to help determine the prevalence of quantifying behaviors, exposures, characteristics as well as diseases at a period (or point) of time, especially in a population that is defined. This information can help to understand the magnitude towards public/environmental health challenge at hand. Qualitative studies usually offer information about the designs of occurrence according to such individual attributes place (e.g., county of residence), (e.g., gender, age, ethnicity), as well as time (e.g., seasonal changes in the patterns of disease). In addition, cross-sectional data may in certain circumstances, offer used information in the design of analytic studies (e.g., baseline information/data toward evaluating the advantages of public/environmental health intervention).

\section{Determining What Is Known From Scientific Literature}

When problem to be addressed are clearly defined, professionals should be knowledgeable of prior or continuing efforts towards resolving the issue. This ought to comprise a systematic method for identifying, retrieving, as well as evaluating appropriate scientific reports based on research, panels, as well as conferences associated toward the issue of interest. The best way to start this investigation is through a formal study of the official literature review. Much databases information is available toward facilitating such a review; the best known of these public/environmental health purposes remain Scirus (Elsevier), MEDLINE Ovid, PubMed, ProQuest Dissertations and theses, CINHAL EBSCO Host, Web of Knowledge, Research Gate, Scopus/Elsevier, Mendeley, Geobase/Elsevier, Environment Complete/Ebsco, Campbell Collaboration databases, Google Scholar, Google Web, SSRN, Academia etc. These subscribed databases through an institution, can selectively remain accessible in the Internet, or occasionally the public can access it from institutions (like the National Library of Medicine [102], Hinari, Universities, Research4life as well as Public libraries). There are also a number of organizations that sustain Internet sites that help identify appropriate information, together with several government health departments, the World Health Organization, Centers for Disease Control and Prevention, as well as the National Institutes of Health etc. It is remarkable to note that the published literature does not cover all (Type 2) intervention studies (see Table 1 above).

\section{Developing And Prioritizing Program Options}

The first three phases examine a number of policy options or health program. The options list can remain expanded from various sources. Preliminary review from scientific literature may occasionally shed light on different priorities options. In most cases, a group of expert panels can provide advice on policy recommendations or program on various issues. A summary of the available evidence is usually provided in systematic reviews and practice guidelines. There are several assumptions or contexts underlying any development of options. These considerations focus on five main areas: political/regulatory, economic, social values, demographic, and technological $[2,3,103]$. Specifically, it is remarkable toward assessing 
as well as monitoring the policy process once developing a crucial option in health policy. Doing so, stakeholder contribution can be suitable. The policy stakeholder may be health policy makers, while community intervention through coalition stakeholder may be a member of the community. With regard to health policies, supportive decision makers may often offer guidance on policy initiatives timing, problem-solving strategies, identifying sponsorship strategies, as well as techniques toward improving general public support. On the topic of community priorities, additional planning information can consist of significant informant interviews, coalition member surveys or focus groups [104].

\section{Developing An Action Plan Together With Implementing Priorities}

This reform procedure has a profound impact on strategic planning snags. As soon as the option has remained carefully chosen, a set of goals as well as objectives must remain developed. The goal is a lasting desired variable in the intervention's status of related health need, as well as short-term objective, measurable, definite action leading in the direction of goal attainment. The action course describes how to achieve the goals together with objectives, what required resources are needed, as well as how accountability aimed at achieving assigned objectives.

\section{Evaluating The Policy Or Program}

Simply put, evaluation is a work experiment that has achieved policy goals as well as program objectives. After established research design, many public/environmental health policies as well as programs are frequently examined using a "quasiexperimental" designs (i.e., people lacking haphazard assignment toward intervention as well as comparison groups). Generally, the strongest appraisal designs recognize the roles of both parametric as well as non-parametric evaluation. In addition, evaluation designs tool must be flexible as well as sensitive enough toward measuring average variability, even individuals falling short of behavioral changes. Genuine variables take incremental place over time, in many ways frequently not known toward those individuals closest to the intervention. 
Table 4

Competencies in Evidence-Based Environmental/Public Health ${ }^{\mathrm{a}}$

\begin{tabular}{|c|c|c|c|c|}
\hline S/N & Title & Domain $^{b}$ & Level $^{c}$ & Competency \\
\hline 1. & $\begin{array}{l}\text { Community } \\
\text { input }\end{array}$ & C & B & $\begin{array}{l}\text { Understand the importance of soliciting public } \\
\text { opinion before planning as well as implementing } \\
\text { interventions that is evidence-based. }\end{array}$ \\
\hline 2. & $\begin{array}{l}\text { Etiologic } \\
\text { knowledge }\end{array}$ & E & B & $\begin{array}{l}\text { Understand the relationship amongst risk factors as } \\
\text { well as diseases. }\end{array}$ \\
\hline 3. & $\begin{array}{l}\text { Community } \\
\text { assessment }\end{array}$ & C & B & $\begin{array}{l}\text { Understand how health issue is defined based on the } \\
\text { needs as well as assets of the population/community } \\
\text { of interest. }\end{array}$ \\
\hline 4. & $\begin{array}{l}\text { Partnerships at } \\
\text { multiple levels }\end{array}$ & $\mathrm{P} / \mathrm{C}$ & B & $\begin{array}{l}\text { Understand the importance of recognizing as well as } \\
\text { developing partnerships to meet the need for routine } \\
\text { evidence-based strategies at various levels. }\end{array}$ \\
\hline 5. & $\begin{array}{l}\text { Developing a } \\
\text { concise } \\
\text { statement of } \\
\text { the issue }\end{array}$ & EBP & B & $\begin{array}{l}\text { Understand the important of developing a concise } \\
\text { statement of the challenges in order to build support } \\
\text { for it. }\end{array}$ \\
\hline 6. & $\begin{array}{l}\text { Grant writing } \\
\text { need }\end{array}$ & $\mathrm{T} / \mathrm{T}$ & B & $\begin{array}{l}\text { Identify the importance of skills in grant writing which } \\
\text { comprise the phases used in the application process. }\end{array}$ \\
\hline 7. & $\begin{array}{l}\text { Literature } \\
\text { searching }\end{array}$ & EBP & B & $\begin{array}{l}\text { Understand how scientific literature is searched as } \\
\text { well as summarize the results of health issue. }\end{array}$ \\
\hline 8. & $\begin{array}{l}\text { Leadership } \\
\text { and evidence }\end{array}$ & L & B & $\begin{array}{l}\text { Identify the need for a strong leadership from } \\
\text { environmental/public health professionals regarding } \\
\text { the need and importance of evidence-based } \\
\text { environmental/public health interventions. }\end{array}$ \\
\hline 9. & $\begin{array}{l}\text { Role of } \\
\text { behavioral } \\
\text { science theory }\end{array}$ & $\mathrm{T} / \mathrm{T}$ & B & $\begin{array}{l}\text { Comprehend the role of behavioral science theory in } \\
\text { implementing, designing, as well as evaluating } \\
\text { strategies. }\end{array}$ \\
\hline 10. & $\begin{array}{l}\text { Leadership at } \\
\text { all levels }\end{array}$ & L & B & $\begin{array}{l}\text { Comprehend the importance of commitment from all } \\
\text { stages of environmental/public health leadership } \\
\text { while improving the use of evidence-based strategies. }\end{array}$ \\
\hline 11. & $\begin{array}{l}\text { Evaluation in } \\
\text { "plain English" }\end{array}$ & EV & I & $\begin{array}{l}\text { Identify the importance of translating the programs } \\
\text { impacts or policies in language that can be } \\
\text { understood by practice sectors, communities as well } \\
\text { as policy makers. }\end{array}$ \\
\hline
\end{tabular}

adapted from Gebbie et al., [88]; Brownson et al., [90]

${ }^{b} C$, community-level planning; $E$, etiology; $P / C$, partnerships and collaboration; $E B P$, evidence-based process; $T / T$, theory and analytic tools; $L$, leadership; $E V$, evaluation; $P$, policy.

${ }^{c} B$, beginner; I, intermediate; $A$, advanced. 


\begin{tabular}{|c|c|c|c|c|}
\hline $\mathrm{S} / \mathrm{N}$ & Title & Domain b & Level $^{c}$ & Competency \\
\hline 12. & $\begin{array}{l}\text { Leadership } \\
\text { and change }\end{array}$ & $\mathrm{L}$ & 1 & $\begin{array}{l}\text { Identify the importance of effective leadership from } \\
\text { professionals environmental/public health when } \\
\text { making decisions in the middle of ever-changing } \\
\text { milieus. }\end{array}$ \\
\hline 13. & $\begin{array}{l}\text { Translating } \\
\text { evidence- } \\
\text { based } \\
\text { interventions }\end{array}$ & EBP & 1 & $\begin{array}{l}\text { Identify the importance of translating evidence-based } \\
\text { strategies to unique "real-world" settings. }\end{array}$ \\
\hline 14. & $\begin{array}{l}\text { Quantifying } \\
\text { the issue }\end{array}$ & $\mathrm{T} / \mathrm{T}$ & 1 & $\begin{array}{l}\text { Comprehend the importance of descriptive } \\
\text { epidemiology (concepts of person, place, time) in } \\
\text { quantifying the environmental/public health } \\
\text { problems. }\end{array}$ \\
\hline 15 & $\begin{array}{l}\text { Developing an } \\
\text { action plan for } \\
\text { program or } \\
\text { policy }\end{array}$ & EBP & 1 & $\begin{array}{l}\text { Comprehend the importance of developing an action } \\
\text { plan that will shows how goals and objectives are to } \\
\text { be achieved, what resources are needed, and how to } \\
\text { share responsibility for achieving assigned } \\
\text { objectives. }\end{array}$ \\
\hline 16. & $\begin{array}{l}\text { Prioritizing } \\
\text { health issues }\end{array}$ & EBP & I & $\begin{array}{l}\text { Comprehend the selection process and implement } \\
\text { relevant criteria as well as processes for prioritizing } \\
\text { program and policy options. }\end{array}$ \\
\hline 17. & $\begin{array}{l}\text { Qualitative } \\
\text { evaluation }\end{array}$ & EV & 1 & $\begin{array}{l}\text { Make sure that the value of qualitative evaluation } \\
\text { approaches together with the steps involved in } \\
\text { conducting qualitative evaluations. }\end{array}$ \\
\hline 18. & $\begin{array}{l}\text { Collaborative } \\
\text { partnerships }\end{array}$ & $\mathrm{P} / \mathrm{C}$ & 1 & $\begin{array}{l}\text { Comprehend the importance of collaborative } \\
\text { partnerships amongst researchers as well as } \\
\text { practitioners when implementing, designing and } \\
\text { evaluating evidence-based policies and programs. }\end{array}$ \\
\hline 19. & $\begin{array}{l}\text { Nontraditional } \\
\text { partnerships }\end{array}$ & $\mathrm{P} / \mathrm{C}$ & I & $\begin{array}{l}\text { Comprehend the importance of traditional } \\
\text { partnerships and those that have been considered } \\
\text { nontraditional for instance those with planners, } \\
\text { transportation department, and others. }\end{array}$ \\
\hline 20. & $\begin{array}{l}\text { Systematic } \\
\text { reviews }\end{array}$ & $\mathrm{T} / \mathrm{T}$ & 1 & $\begin{array}{l}\text { Comprehend the rationale, uses, as well as } \\
\text { systematic reviews usefulness that document } \\
\text { effective strategies. }\end{array}$ \\
\hline 21 & $\begin{array}{l}\text { Quantitative } \\
\text { evaluation }\end{array}$ & EV & I & $\begin{array}{l}\text { Comprehend the importance of quantitative } \\
\text { evaluation methods together with the concepts of } \\
\text { measurement validity as well as reliability. }\end{array}$ \\
\hline
\end{tabular}

aAdapted from Gebbie et al., [88]; Brownson et al., [90]
${ }^{b} C$, community-level planning; E, etiology; P/C, partnerships and collaboration; EBP, evidence-based
process; $T / T$, theory and analytic tools; $L$, leadership; EV, evaluation; P, policy.
${ }^{c} B$, beginner; I, intermediate; $A$, advanced. 


\begin{tabular}{|c|c|c|c|c|}
\hline $\mathrm{S} / \mathrm{N}$ & Title & Domain b & Level $^{c}$ & Competency \\
\hline 22 & $\begin{array}{l}\text { Grant writing } \\
\text { skills }\end{array}$ & $\mathrm{T} / \mathrm{T}$ & I & $\begin{array}{l}\text { Demonstrate the ability toward creating a grant } \\
\text { together with an outline of the steps involved in the } \\
\text { application procedure. }\end{array}$ \\
\hline 23 & $\begin{array}{l}\text { Role of } \\
\text { economic } \\
\text { evaluation }\end{array}$ & $\mathrm{T} / \mathrm{T}$ & A & $\begin{array}{l}\text { Identifying the importance of using economic data as } \\
\text { well as strategies toward evaluating costs and } \\
\text { consequences when making public/environmental } \\
\text { health decisions. }\end{array}$ \\
\hline 24 & $\begin{array}{l}\text { Creating policy } \\
\text { briefs }\end{array}$ & $\mathrm{P}$ & $A$ & $\begin{array}{l}\text { Comprehend the importance of writing concisepolicy } \\
\text { briefs toward considering the problem using } \\
\text { evidence-based strategies. }\end{array}$ \\
\hline 25 & $\begin{array}{l}\text { Evaluation } \\
\text { designs }\end{array}$ & EV & A & $\begin{array}{l}\text { Understand the different designs that is useful in } \\
\text { program evaluation with a specific focus on quasi- } \\
\text { experimental (nonrandomized) designs. }\end{array}$ \\
\hline 26 & $\begin{array}{l}\text { Transmitting } \\
\text { evidence- } \\
\text { based research } \\
\text { to policy } \\
\text { makers }\end{array}$ & $P$ & A & $\begin{array}{l}\text { Comprehend the importance of coming up with } \\
\text { creative as well as novel ways of transmitting what } \\
\text { we know works (evidence-based interventions) } \\
\text { toward policy makers in order to gain interest, } \\
\text { political support, and funding. }\end{array}$ \\
\hline \multicolumn{5}{|c|}{ aAdapted from Gebbie et al., [88]; Brownson et al., [90] } \\
\hline \multicolumn{5}{|c|}{$\begin{array}{l}{ }^{b} C, \text { community-level planning; } E \text {, etiology; } P / C \text {, partnerships and collaboration; } E B P \text {, evidence-based } \\
\text { process; } T / T \text {, theory and analytic tools; } L \text {, leadership; EV, evaluation; } P \text {, policy. }\end{array}$} \\
\hline
\end{tabular}

\section{Barriers To More Extensive Use Of Evidence In Decision Making}

There are several barriers to more effective use of data and analytic processes in decision making [58, $105,106]$ (Table 5). Possible approaches for overcoming these barriers have been discussed by others [2, $3,91]$. Leadership is needed from environmental/public health practitioners on the need and significance of evidence-based decision making. Such leadership is evident in training programs, such as the regional leadership network for environmental/public health practitioners, [98] and the ongoing efforts under way to develop and disseminate evidence-based guidelines for interventions [72]. 
Table 5

Potential Barriers and Solutions for Use of Evidence-Based Decision Making in Environmental/Public Health

\begin{tabular}{|c|c|c|}
\hline$S / N$ & Barrier & Potential Solution \\
\hline 1. & Inadequate resources & $\begin{array}{l}\text { Commitment to increase funding for prevention } \\
\text { and rectifying staff shortages }\end{array}$ \\
\hline 2. & $\begin{array}{l}\text { Leadership lacks and uncertainty in } \\
\text { setting a clear and focused agenda for } \\
\text { evidence-based approaches }\end{array}$ & $\begin{array}{l}\text { Commitment from all levels of } \\
\text { environmental/public health leaders to increase } \\
\text { the understanding of the value of EBEPH } \\
\text { approaches }\end{array}$ \\
\hline 3. & $\begin{array}{l}\text { Inadequate incentives for using evidence- } \\
\text { based approaches }\end{array}$ & $\begin{array}{l}\text { Identification of new ways of shaping } \\
\text { organizational culture toward supporting EBEPH }\end{array}$ \\
\hline 4. & $\begin{array}{l}\text { Inadequate view of the long-term "horizon" } \\
\text { for program implementation and } \\
\text { evaluation }\end{array}$ & $\begin{array}{l}\text { Adoption and adherence to causal frameworks } \\
\text { and formative evaluation plans }\end{array}$ \\
\hline 5. & $\begin{array}{l}\text { External (including political) pressures } \\
\text { drive the process away from an evidence- } \\
\text { based approach }\end{array}$ & $\begin{array}{l}\text { Systematic communication and dissemination } \\
\text { strategies }\end{array}$ \\
\hline 6. & $\begin{array}{l}\text { Inadequate training in key public health } \\
\text { disciplines }\end{array}$ & $\begin{array}{l}\text { Wider dissemination of new and established } \\
\text { training programs, including use of distance } \\
\text { learning technologies }\end{array}$ \\
\hline 7. & $\begin{array}{l}\text { Inadequate time to gather information, } \\
\text { analyze data, and review the literature for } \\
\text { evidence }\end{array}$ & $\begin{array}{l}\text { Enhanced skills for efficient analysis and review } \\
\text { of the literature, computer searching abilities, } \\
\text { use of systematic reviews }\end{array}$ \\
\hline 8. & $\begin{array}{l}\text { Inadequate evidence on the effectiveness } \\
\text { of certain environmental/public health } \\
\text { interventions for special populations }\end{array}$ & $\begin{array}{l}\text { Increased funding for applied } \\
\text { environmental/public health research; better } \\
\text { dissemination of findings }\end{array}$ \\
\hline 9. & $\begin{array}{l}\text { Inadequate information on } \\
\text { implementation of interventions }\end{array}$ & $\begin{array}{l}\text { A greater emphasis on building the evidence } \\
\text { base for external validity }\end{array}$ \\
\hline
\end{tabular}

However, there are many factors that influence decision making in environmental/public health $[107,108]$ (see Table 6 below). Some of these factors are under the control of the environmental/public health practitioners, whereas others are nearly impossible to modify. 
Table 6

Factors Influencing Decision Making among Environmental/Public Health Administrators, Decision Makers, and the General Public.

\begin{tabular}{|c|c|}
\hline Category & Influential Factor \\
\hline \multirow[t]{2}{*}{ Information } & -Sound scientific basis, including knowledge of causality \\
\hline & $\begin{array}{l}\text {-Source (e.g., professional organization, government, mass } \\
\text { media, friends) }\end{array}$ \\
\hline \multirow[t]{5}{*}{ Clarity of contents } & •Formatting and framing \\
\hline & •Perceived validity \\
\hline & -Perceived relevance \\
\hline & -Cost of intervention \\
\hline & -Strength of the message (i.e., vividness) \\
\hline \multirow{9}{*}{$\begin{array}{l}\text { Perceived values, preferences, } \\
\text { beliefs }\end{array}$} & -Role of the decision maker \\
\hline & •Economic background \\
\hline & $\cdot$ Previous education \\
\hline & -Personal experience or involvement \\
\hline & •Political affiliation \\
\hline & -Willingness to adopt innovations \\
\hline & -Willingness to accept uncertainty \\
\hline & -Willingness to accept risk \\
\hline & •Ethical aspect of the decision \\
\hline \multirow[t]{5}{*}{ Context } & •Culture \\
\hline & •Politics \\
\hline & $\cdot$ Timing \\
\hline & -Media attention \\
\hline & •Financial or political constraints \\
\hline
\end{tabular}

Source: Adapted from Anderson et al. [108]; Brownson et al., [38] and Raimi et al., [2].

Also, there are quite at least four techniques in which environmental/public health policy or program cannot achieve a specific success goal:

i. Choose an intervention forms whose effectiveness in scientific literature has not yet been confirmed.

ii. Choosing a policy or program that may be effective but only attaining frail, partial implementation or "reach," thus worsening to accomplish the objectives (few call this Type III error) 
iii. Assessing insufficient or improper evaluation that led to public ignorance of the impacts of a policy or program

iv. Paying insufficient consideration toward acclimatizing an intervention between population as well as background interest.

However, part of the reason that environmental/public health-policy officials have struggled in the face of the COVID-19, is that it's very difficult to identify appropriate interventions that might inspire people to change their behaviours given reasons. For instance, do people who won't wear masks think the virus isn't risky, since they don't think masks work, or just as their leaders including others aren't wearing them? To make matters worse, surveys or studies often represent only a portion of the population leaving those most at risk underrepresented. "Data can be instructive, but it does not speak for itself, as data access remains one of the primary hurdles to advancing science". "Behind every data point is a person. And with something like the coronavirus, where people are so deeply affected, there is need to think about the ethics of intervening in people's lives."

\section{Addressing The Issue}

While the coronavirus continues to surge globally, the COVID-19 pandemic continues to put the health and economic security of millions of Nigerians and the world at large at risk, evidence is building and has accumulated over the course of the COVID-19 pandemic, scientific understanding about the virus has changed. Overall, to enhance evidence-based practice, all possibilities must attempt to provide practical guidance on how to select, carry out, and evaluate evidence-based programs and policies in environmental/public health settings. It also begins to address the need for a highly trained environmental/public health workforce and expand available technology, hence, research into the causes of infectious diseases and the development of vaccines and pharmaceuticals quelled once-devastating illnesses such as polio, smallpox and now COVID-19. Thus, the successful EBE/PH implementation in the practice of public/environmental health is both scientific as well as art. Science is based on behavioral, epidemiologic, as well as policy research that reflects the size with the magnitude of the public/environmental health issues and which interventions probable are to be of advantage to problem solving. The policy-making art experience usually comprises understanding of what information that is significant toward a specific stakeholder at the appropriate time. Remarkable environmental/public health decisions should balance science as well as art, because rational, scientific-based policy making that frequently comprises selecting an option amongst set of choices that are rational in nature.

By using the outlined concepts in EBE/PH above, decision making are ultimately improving the environmental/public health practice; this is especially important in a time when environmental/public health practitioners should be incentivized, not disincentivized, to provide remote and long-term care and if successfully implemented and continued in the post COVID era, these efforts could enjoy the welcome consequence of cost savings and efficiency $[3,4,5,15,16]$. These efforts can help in tailoring efficacious interventions for improving the COVID-19 pandemic response. 
However, suppression of the COVID-19 pandemic, cannot rely solely on the hope of effective vaccines and/or medical treatment, especially having the new, fast spreading SARS-CoV-2 variants: there is need for a "Plan B" of effective behavioural, environmental, social and systems interventions (BESSI) to reduce transmission. Given the Covid-19 pandemic is likely to be around to at least first quarter of 2022 (potentially followed by seasonal outbreaks), even if a vaccine or effective treatments are developed, it is imperative to address Behavioural, Environmental, Social and Systems Interventions (BESSI) evidence gaps now and to develop longer-term research priorities and processes to improve evidence about BESSI Interventions to prevent and manage future infectious disease outbreaks through fostering research synthesis, systems thinking, incorporating interprofessionalism and team-based care, prioritization, piloting, and field trials in collaboration with health organisations, policy makers, communities, and a range of researchers relevant to BESSI research strategy (see Fig. 5 below).

Furthermore, there is need to fund evidence-based projects that will focus on identifying a health or disease condition for which there is need for intervention and community support and engagement to address the problem, articulate a process for ensuring cultural appropriateness and recognizing community strengths and resiliencies, advancing knowledge toward addressing the health or disease condition through etiologic research, prevention research, building robust frameworks for governance, oversight, and accountability, treatment or recovery research, or dissemination and implementation research and accounting for sustainability in test communities and for dissemination and scale up to other communities as indicated. Hence, real-world evidence could significantly improve public health (social medicine, preventive medicine, community health and community medicine) decisions across the health system and ultimately improve environmental health. Expanding its use, however, will require multi-stakeholder action on several priorities, as well as country-specific campaigns. Therefore, the broad environmental/public health community is best equipped to make progress towards addressing individual behaviors, social conditions, or environmental conditions related to a disease or disorder. Thereby, making progress on these goals will help establish the kind of culture where evidence-based innovation will flourish, while ensuring that necessary, complementary capabilities exist to support traditional research and development (R\&D) activities.

Likewise, governments at all levels must act expeditiously and decisively to provide robust support for crucial domestic environmental/public health and health care programs, medical countermeasures development, global preparedness programs and response mechanism and international partnerships. In order to mitigate the impacts of the virus. There is need for national and international response prompt action now and is needed to avoid worst case health and economic consequences. Based on the known facts surrounding the current pandemic, it appears that government must urgently take additional steps now to prepare domestically to invest globally and to help make the shift from containment of the virus to mitigation of its effects. This shift will be difficult, and the response will be exceptionally resources intensive. Readiness and response to health security threats like COVID-19 is as critical to the safety and well-being of humanity. Emergency preparedness have been essential for increasing national resilience and capacities to combat health risk emergencies. There is need to build systems to strengthen evidence- 
based research and expertise must be continued and boistered. Aimed at reducing illness and death in the current dark times and time to come.

The COVID-19 pandemic provides a unique opportunity to discuss critical issues related to defining living reviews and how often they should be conducted. It has significantly accelerated the production of living reviews as a useful tactic toward informing decision makers in a context where evidence is constantly evolving on a regular (sometimes even on a daily basis). Since 'living' reviews are most useful in a context where information is changing relatively frequently on a topic, so hopefully an update is expected to be happening at pace with evolving literature. From this perspective, part of the requirements of a living review should be that there is a positive plan to monitor for new relevant data or evidence, and a plan for managing this evidence when it emerges. Hence, there is needs to be a plan for incorporating new information as it emerges, with the aim that decisions that are made on the basis of the reviews can be relied on or trusted to be informed by the best current evidence. Thus, the framework above provides an important Living Evidence Network criterion from a positive sense (i.e., the question must be an important priority, there is uncertainty in the outcomes, and that new forthcoming evidence can likely improve this certainty). It is important to assess whether or not the review should no longer be updated on a living basis if at least one of these characteristics are no longer true. As we have seen with COVID-19, the frequency of updating may vary depending on the rate at which new research is coming through and its likely impact on the evidence base, but whatever frequency is adopted this needs to be communicated clearly together with the intent to keep the review under active surveillance. While, communicating with users and readers about the currency and comprehensiveness of the evidence.

As the Chinese proverb used to say "Problems give opportunity and changes, and the gods cannot help those who do not take advantage of this opportunity". Out of a disaster provide opportunities toward building a safer, healthier, as well as a more just world. In all these domains, addressing health toughest triage will be crucial and will help strengthen and maintain the scientific integrity as well as political neutrality of environmental and human health action in the times of concomitant global crises. Of course, this is not only a response toward COVID-19, but also for the full gamut of health challenges. Time has come toward revitalizing and rethinking governance, policies, as well as investments in scientific research for better health, which precede a more sustainable future for global as well as national health leadership in preparedness, response, and health recovery for emergencies, which will necessitate a range of research methods and analytic decisions. Increased focused attention toward these approaches and analytic decisions has the potential toward increasing the importance of policies and its uses towards health systems strengthening, hence potentially assisting policy makers towards improving mitigation efficiency while concurrently improving global and national health, with an attempt toward drawing remarkable lessons for strengthening pandemic preparedness as well as response. While the response to COVID-19 is constantly evolving and the situation is constantly changing, how a country respond to an outbreak depends on the resilient of its health systems, effective response is needed to fight the immediate outbreak and reduce its downstream impact on health. In general, environmental and public health research analyses as well as comprehensive health systems in all countries which may include integrated core capacities for environmental/public health at all governance levels, will be the best 
protection/defense against other major great pandemic outbreak. Therefore, effective national planning/preparedness necessitates clearly understanding states situation' ability toward predicting, managing and balancing public/environmental health needs at all stages of the pandemic. This requires leveraging data for rapid, accurate and responsibly impacting on sound public/environmental health policies, hence, converting this intelligence into actionable solutions will thereby ensure shared accountability. The demarcation between action and inaction is seldom distinct and requires careful consideration of scientific evidence as well as assessment of values, preferences, costs, and benefits of various options. Hence, these findings and their likely explanation point to the need for much better evidence. There is therefore need for evidence about the risks and benefits of COVID-19 discrete, biologically targeted interventions and how these risks and benefits vary across different subgroups of the population. Other recommendations include:

1. Investment in Behavioural Environmental Social and System Intervention (BESSI): Whilst the limited investment in BESSIs to date is a missed opportunity, we should learn from this pandemic to prepare for rapid, effective response to future pandemics. As BESSI collaboration should help develop rigorous "research in action", with researchers and those tasked with implementing programmes working together. Thus, there is need to consider how to efficiently set research priorities and how to work more closely with $\mathrm{WHO}$ which potentially has the infrastructure to collate BESSI protocols that might be developed and then adapted for future pandemics. While a few examples of this have occurred, many public/environmental health and clinical services have felt too overwhelmed to engage with researchers, but clearly it is possible and we can learn from those that did engage.

2. Collective Collaboration/Partnership: Geographical hubs for BESSI collaborators will enable meaningful research interactions and activities between the global north and south. There is need to avoid designing research in the global north and then contextualising it for the south. This interaction needs to be bidirectional and co-designed. As BESSI need to focused on funders, researchers, and major international organisations, while there is need to start to engage with some health professional organisations such as WFPHA, EHORCON, PAHO, etc.

3. Emphasis on Practice-Based Research: Research in environmental health is incremental, through a body of scientifically compiled evidence over a period of several years or decades. Hence, environmental health information for decision making should be founded on science, and science is based on the collection, analysis, and interpretation of data. Data in environmental/public health are generally derived from two overlapping sources: research studies and environmental/public health surveillance systems. Indeed, there is the need for a more practice-based research in which environmental/public health practitioners routinely collect as well as record data on the COVID-19 treatment and outcomes of their patients in order to better care for those in the future? Hence, there is pressing need for evidence development. More and better evidence including comparative as well as longitudinal data is required to determine the effectiveness and usefulness of novel medical interventions, drugs, treatments, devices, and genetic information.

4. Clear Uncertainty: The uncertainty exposed through the information environment. An irony of the information-rich environment is that information imperative for decision making is frequently not 
available, or is provided in ways that are not relevant to the broad spectrum of patients with differing levels of health, socioeconomic circumstances, and preferences, as well as the issues encountered in practice. This is due to too little research effectiveness, to poor evidence dissemination that is available, and to too few incentives as well as decision supports for evidence-based care. Hence, there is need for a rapid review on public/environmental health topics driving by: 1) emergence of new evidence (sometimes even on a daily basis $2-3$ months into the pandemic; 2 ) research designs of available evidence, and likelihood that more rigorous designs may provide greater certainty in the findings; and 3) emergence of evidence that 'add's something new'. Also, it is found that the frequency of updating a living review has changed from earlier in the pandemic to now.

5. Capable and Credible Leadership: Leadership that stems from every quarter. Adapting to and taking advantage of the changes in the healthcare environment will take broad leadership. A strategic focus on the development and application of evidence will require the involvement of both the public and private sectors working together, and of policy makers, providers, patients, insurers, and other development partners in the steps toward change. Else, there is need for a shift toward a culture of collective learning. To develop best evidence for environmental/public health delivery that is geared toward the needs of individual patients (see Table 2 above), investment is needed into infrastructure for the gathering and analysis of healthcare data and information, as well as standards and protocols to ensure their accuracy and reliability. This changing role will require healthcare providers and patients to adopt a culture that supports the generation and application of evidence.

\section{Declarations}

\section{Acknowledgements}

I thank all anonymous reviewers, for feedback and discussions that helped to substantially improve this manuscript.

\section{Authors' contributions}

All authors included in the manuscript provided substantial contribution to (i) conception and design, (ii) drafting the article or revising it critically for important intellectual content and (iii) final approval of the completed manuscript.

\section{Declaration of competing interests}

We affirm that we have no conflict of interest that may be alleged as prejudicing the impartiality of the study reported. This researcher did not receive special assistance from government, not-for-profit sectors or commercial institutions.

\section{Abbreviations}

HIA 
Health Impact Assessment

WFPHA

World Federation of Public Health Associations

$\mathrm{PAHO}$

Pan American Health Organization

SDoH

Social Determinant of Health

BESSI

Behavioural Environmental Social and System Intervention

EHORCON

Environmental Health Officers Registration Council of Nigeria

\section{References}

1. Morufu Olalekan Raimi, Ebikapaye Okoyen, Tuebi Moses, Aziba-anyam Gift Raimi, Adedoyin Oluwatoyin Omidiji, Aishat Funmilayo Abdulraheem, Mariam Oluwakemi Raimi, Beatrice Oka Joseph (2021) Do Weak Institutions Prolong Crises? [\#ENDSARs] in the Light of the Challenges and opportunities beyond COVID-19 Pandemic and the Next Normal in Nigeria. Communication, Society and Media. ISSN 2576-5388 (Print) ISSN 2576-5396 (Online) Vol. 4, No. 2, DOI: https://doi.org/10.22158/csm.v4n2p1. http://www.scholink.org/ojs/index.php/csm/article/view/3790.

2. Raimi Morufu Olalekan, Moses Tuebi, Okoyen Ebikapaye, Sawyerr Henry Olawale, Joseph Beatrice Oka, Oyinlola Bilewu Olaolu (2020) “A Beacon for Dark Times: Rethinking Scientific Evidence for Environmental and Public Health Action in the Coronavirus Diseases 2019 Era" Medical and Research Microbiology, 1, Issues 3.

3. Raimi Morufu Olalekan \& Raimi Aziba-anyam Gift (2020). The Toughest Triage in Decision Impacts: Rethinking Scientific Evidence for Environmental and Human Health Action in the Times of Concomitant Global Crises. CPQ Medicine, 11(1), 01-05.

4. Olalekan RM, Olawale SH, Christian A, Simeon AO (2020). Practitioners Perspective of Ethical Cases and Policy Responses by Professional Regulator: The Case of Environmental Health Officers Registration Council of Nigeria (EHORECON). American Journal of Epidemiology \& Public Health. 2020;4(1): 016-023. https://www.scireslit.com/PublicHealth/AJEPH-ID23.pdf. https://www.scireslit.com/PublicHealth/articles.php?volume=4\&issue=1.

5. Olalekan RM (2020). "What we learn today is how we behave tomorrow": a study on satisfaction level and implementation of environmental health ethics in Nigeria institutions. Open Access Journal of Science, 4(3):82-92. DOI: 10.15406/oajs.2020.04.00156.

6. Olalekan RM, Muhammad IH, Okoronkwo UL, Akopjubaro EH (2020). Assessment of safety practices and farmer's behaviors adopted when handling pesticides in rural Kano state, Nigeria. Arts \& Humanities Open Access Journal. 2020;4(5):191-201. DOI: 10.15406/ahoaj.2020.04.00170. 
7. Gift R.A, Obindah $F$ (2020). Examining the influence of motivation on organizational productivity in Bayelsa state private hospitals. Open Access Journal of Science. 2020;4(3):94-108. DOI: 10.15406/oajs.2020.04.00157.

8. Gift RA, Olalekan RM, Owobi OE, Oluwakemi RM, Anu B, Funmilayo AA (2020). Nigerians crying for availability of electricity and water: a key driver to life coping measures for deepening stay at home inclusion to slow covid-19 spread. Open Access Journal of Science. 2020;4(3):69-80. DOI: 10.15406/oajs.2020.04.00155.

9. Gift R A, Olalekan RM (2020). Access to electricity and water in Nigeria: a panacea to slow the spread of Covid-19. Open Access Journal of Science 2020;4(2):34. DOI: 10.15406/oajs.2020.04.00148. https://medcrave.com/index.php?/articles/det/21409/

10. Morufu Olalekan Raimi, Tonye Vivien Odubo \& Adedoyin Oluwatoyin Omidiji (2021) Creating the Healthiest Nation: Climate Change and Environmental Health Impacts in Nigeria: A Narrative Review. Scholink Sustainability in Environment. ISSN 2470-637X (Print) ISSN 2470-6388 (Online) Vol. 6, No. 1, 2021 scholink.org/ojs/index.php/se. URL: http://dx.doi.org/10.22158/se.v6n1p61. http://www.scholink.org/ojs/index.php/se/article/view/3684.

11. Raimi Morufu Olalekan, Omidiji Adedoyin O, Ebikapaye Okoyen, Moses Tuebi, Adeolu Timothy Adedotun, Makanjuola Bosede Christianah (2019), Situational Analysis of National Immunization Programme in Nigeria, Journal of Immunology and Inflammation Diseases Therapy. Doi: http://dx.doi.org/10.31579/2637-8876.2019/008.

12. Olalekan R. M, Dodeye E. O, Efegbere H. A, Odipe O. E. Deinkuro N. S, Babatunde A and Ochayi E. O (2020) Leaving No One Behind? Drinking-Water Challenge on the Rise in Niger Delta Region of Nigeria: A Review. Merit Research Journal of Environmental Science and Toxicology (ISSN: 23502266) Vol. 6(1): 031-049 DOI: 10.5281/zenodo.3779288

13. Olalekan RM, Omidiji AO, Williams EA, Christianah MB, Modupe O (2019). The roles of all tiers of government and development partners in environmental conservation of natural resource: a case study in Nigeria. MOJ Ecology \& Environmental Sciences 2019;4(3):114-121. DOI: 10.15406/mojes.2019.04.00142.

14. Raimi MO, Ochayi EO, Babatunde A, Okolosi-Patani IE, Oluwaseun EO, Adio ZO and Bilewu OO (2019) "Environmental Ethics Relevance to Public Health: Current Narratives and Implications for Policy". EC Emergency Medicine and Critical Care12:01-09.

15. Raimi MO, Ihuoma BA, Esther OU, Abdulraheem AF, Opufou T, Deinkuro NS, Adebayo PA and Adeniji AO (2020) "Health Impact Assessment: Expanding Public Policy Tools for Promoting Sustainable Development Goals (SDGs) in Nigeria". EC Emergency Medicine and Critical Care9 (2020).

16. Olalekan RM, Oluwatoyin OA, Olawale SH, Emmanuel OO, Olalekan AZ (2020) A Critical Review of Health Impact Assessment: Towards Strengthening the Knowledge of Decision Makers Understand Sustainable Development Goals in the Twenty-First Century: Necessity Today; Essentiality Tomorrow. Research and Advances: Environmental Sciences. 2020(1): 72-84. DOI: 10.33513/RAES/2001-13. https://ospopac.com/journal/environmental-sciences/early-online. 
17. Olalekan R. M, Oluwatoyin $O$ and Olalekan A (2020) Health Impact Assessment: A tool to Advance the Knowledge of Policy Makers Understand Sustainable Development Goals: A Review. ES Journal of Public Health; 1(1); 1002.

https://escientificlibrary.com/public-health/in-press.php.

18. Samson T.K., Ogunlaran O.M., Raimi O.M. (2020); A Predictive Model for Confirmed Cases of COVID19 in Nigeria. European Journal of Applied Sciences, Volume 8, No 4, Aug 2020; pp:1-10. DOI: 10.14738/aivp.84.8705. URL: http://dx.doi.org/10.14738/aivp.84.8705.

19. Omidiji A. O and Raimi M. O (2019) Practitioners Perspective of Environmental, Social and Health Impact Assessment (ESHIA) Practice in Nigeria: A Vital Instrument for Sustainable Development. Paper Presented at the Association for Environmental Impact Assessment of Nigeria (AEIAN) On Impact Assessment: A Tool for Achieving the Sustainable Development Goals in Nigeria, 7th and 8th November, 2019 In University of Port Harcourt. https://aeian.org/wp-content/uploads/2019/08/EIAPresentations-Portharcourt.pdf.

20. Raimi M. O, Omidiji A. O, Adio Z. O (2019) Health Impact Assessment: A Tool to Advance the Knowledge of Policy Makers Understand Sustainable Development Goals. Conference paper presented at the: Association for Environmental Impact Assessment of Nigeria (AEIAN) On Impact Assessment: A Tool for Achieving the Sustainable Development Goals in Nigeria, 7th and 8th November, 2019 in University of Port Harcourt. DOI: 13140/RG.2.2.35999.51366 https://www.researchgate.net/publication/337146101.

21. Adedoyin OO, Olalekan RM, Olawale SH, et al (2020). A review of environmental, social and health impact assessment (Eshia) practice in Nigeria: a panacea for sustainable development and decision making. MOJ Public Health. 2020;9(3):81-87. DOI: 10.15406/mojph.2020.09.00328. https://medcraveonline.com/MOJPH/MOJPH-09-00328.pdf.

22. Raimi Morufu Olalekan (2019) $21^{\text {st }}$ Century Emerging Issues in Pollution Control. $6^{\text {th }}$ Global Summit and Expo on Pollution Control May 06-07, 2019 Amsterdam, Netherlands.

23. Raimi Morufu Olalekan, Tonye V. Odubo, Omidiji Adedoyin O, Oluwaseun E. Odipe (2018) Environmental Health and Climate Change in Nigeria. World Congress on Global Warming. Valencia, Spain. December 06-07, 2018.

24. Nicola M, Alsafi Z, Sohrabi C, Kerwan A, et al. (2020) The socio-economic implications of the coronavirus pandemic (COVID-19): a review. Int J Surg; 78: 185-93.

25. Jenicek M. (1997) Epidemiology, evidence-based medicine, and evidence-based public health. $J$ Epidemiol Commun Health; 7: 187 - 197.

26. Kohatsu ND, Robinson JG, Torner JC (2004). Evidence-based public health: an evolving concept. Am J Prev Med. 27 (5): 417 - 421.

27. Chambers D, Kerner J. (2007) Closing the gap between discovery and delivery. Dissemination and Implementation Research Workshop: Harnessing Science to Maximize Health, Rockville, MD. 
28. Morufu Olalekan Raimi, Tonye Vivien Odubo, Ogah Alima, Henry Akpojubaro Efegbere, Abinotami Williams Ebuete (2021) Articulating the effect of Pesticides Use and Sustainable Development Goals (SDGs): The Science of Improving Lives through Decision Impacts. Research on World Agricultural Economy. Vol 2, No. 1. DOI: http://dx.doi.org/10.36956/rwae.v2i1.347.

29. McKean E. (2005). The New Oxford American Dictionary. 2nd ed. New York, NY: Oxford University Press.

30. Rimer BK, Glanz DK, Rasband G. (2001) Searching for evidence about health education and health behavior interventions. Health Educ Behav, 28 (2): 231 - 248.

31. Kerner JF. (2008) Integrating research, practice, and policy: what we see depends on where we stand. J Public Health Manag Pract; 14 (2): 193 - 198.

32. Mulrow CD, Lohr KN. (2001) Proof and policy from medical research evidence. $J$ Health Polit Policy Law, 26 (2): $249-266$.

33. Sturm R. (2002) Evidence-based health policy versus evidence-based medicine. Psychiatr Serv, 53 (12): 1499.

34. Suleiman Romoke Monsurat, Raimi Morufu Olalekan and Sawyerr Henry Olawale (2019) A Deep Dive into the Review of National Environmental Standards and Regulations Enforcement Agency (NESREA) Act. International Research Journal of Applied Sciences. pISSN: 2663-5577, elSSN: 26635585. DOI No. Irjas.2019.123.123. scirange.com. https://scirange.com/abstract/irjas.2019.108.125.

35. Brownson RC, Royer C, Ewing R, et al. (2006) Researchers and policymakers: travelers in parallel universes. Am J Prev Med; 30 (2): 164 - 172.

36. Muir Gray JA. (1997) Evidence-Based Healthcare: How to Make Health Policy and Management Decisions. New York and Edinburgh: Churchill Livingstone.

37. Rychetnik L, Hawe P, Waters E, et al. (2004) A glossary for evidence based public health. J Epidemiol Commun Health; 58 (7): 538 - 545.

38. Brownson RC, Elizabeth AB, Terry LL, Kathleen NG, William RT (2011). Evidence-Based Public Health. Second Edition. Oxford University Press, Inc. ISBN 978-0-19-539789-51.

39. Nutbeam D (2003). How does evidence influence public health policy? Tackling health inequalities in England. Health Promot J 2003; 14: 154 - 158.

40. Ogilvie D, Egan M, Hamilton V, Petticrew M (2005). Systematic reviews of health effects of social interventions: 2. Best available evidence: how low should you go? J Epidemiol Community Health; 59 (10): $886-892$.

41. Hussain Muhammad Isah, Morufu Olalekan Raimi, Henry Olawale Sawyerr (2021) Patterns of Chemical Pesticide Use and Determinants of Self-Reported Symptoms on Farmers Health: A Case Study in Kano State for Kura Local Government Area of Nigeria. Research on World Agricultural Economy. Vol 2, No. 1. DOl: http://dx.doi.org/10.36956/rwae.v2i1.342.

42. Isah, H. M., Sawyerr, H. O., Raimi, M. O., Bashir, B. G., Haladu, S. \& Odipe, O. E. (2020). Assessment of Commonly Used Pesticides and Frequency of Self-Reported Symptoms on Farmers Health in Kura, 
Kano State, Nigeria. Journal of Education and Learning Management (JELM), HolyKnight, vol. 1, 31 54. doi.org/10.46410/jelm.2020.1.1.05. https://holyknight.co.uk/journals/jelm-articles/.

43. Isah Hussain Muhammad, Raimi Morufu Olalekan, Sawyerr Henry Olawale, Odipe Oluwaseun Emmanuel, Bashir Bala Getso, Suleiman Haladu (2020) Qualitative Adverse Health Experience Associated with Pesticides Usage among Farmers from Kura, Kano State, Nigeria. Merit Research Journal of Medicine and Medical Sciences (ISSN: 2354-323X) Vol. 8(8) pp. 432-447, August, 2020. DOI: 10.5281/zenodo.4008682.

https://meritresearchjournals.org/mms/content/2020/August/lsah\%20et\%20al.htm.

44. Morufu Olalekan Raimi (2021). "Self-reported Symptoms on Farmers Health and Commonly Used Pesticides Related to Exposure in Kura, Kano State, Nigeria". Annals of Community Medicine \& Public Health. 1(1): 1002. http://www.remedypublications.com/open-access/self-reported-symptoms-onfarmers-health-and-commonly-used-pesticides-related-6595.pdf. http://www.remedypublications.com/annals-of-community-medicine-public-health-home.php.

45. Abdulraheem A. FO, Olalekan R. M, Abasiekong E. M (2018) Mother and father adolescent relationships and substance use in the Niger delta: a case study of twenty-five (25) communities in Yenagoa local government of Bayelsa state, Nigeria. Sociol Int J. 2018;2(6):541-548. DOI: 10.15406/sij.2018.02.00097.

46. Funmilayo A. A, Robert O. T, Olalekan R. M, Okoyen E, Tuebi M (2019). A study of the context of adolescent substance use and patterns of use in yenagoa local government, Bayelsa State, Nigeria. MOJ Addiction Medicine and Therapy. 2019;6(1):25-32. DOI: 10.15406/mojamt.2019.06.00142.

47. Raimi MO, Abdulraheem AF, Major I, Ebikapaye O, Bilewu OO (2019). Public Health Impact of Substance Use on Adolescent: A Snapshot of Yenagoa in Bayelsa State, Nigeria.American Journal of Biomedical Science \& Research. 4(3). AJBSR.MS.ID.000796. DOI: 10.34297/AJBSR.2019.04.000796. https://biomedgrid.com/current-issue.php.

48. Glasgow RE, Green LW, Klesges LM, et al (2006). External validity: we need to do more. Ann Behav Med; 31 (2): 105 - 108.

49. Green LW, Glasgow RE (2006). Evaluating the relevance, generalization, and applicability of research: issues in external validation and translation methodology. Eval Health Prof; 29 (1): 126 - 153.

50. McQueen DV (2002). The evidence debate. J Epidemiol Commun Health; 56 (2): 83 - 84.

51. Cavill N, Foster C, Oja P, et al (2006). An evidence-based approach to physical activity promotion and policy development in Europe: contrasting case studies. Promot Educ; 13 (2): 104 - 111.

52. Raimi MO, and Ochayi EO. (2017) Assessment of the Rate of Sexually Transmitted Diseases in Kubwa F.C.T. Abuja, Nigeria, Science Journal of Public Health. Vol. 5, No. 5, 2017, Pp. 365-376. DOI: 10.11648/J.Sjph.20170505.12.

53. Sawyerr O. H, Odipe O. E, Olalekan R. M, et al. (2018) Assessment of cyanide and some heavy metals concentration in consumable cassava flour "lafun" across Osogbo metropolis, Nigeria. MOJ Eco Environ Sci. 2018;3(6):369-372. DOI: 10.15406/mojes.2018.03.00115. 
54. Raimi MO., Oluwaseun EO, Nimisingha DS, Abdulraheem AF, Okolosi-Patainnocent E, Habeeb ML and Mary F (2019) Assessment of Environmental Sanitation, Food Safety Knowledge, Handling Practice among Food Handlers of Bukateria Complexes in lju Town, Akure North of Ondo-State, Nigeria. Acta Scientific Nutritional Health 6 (2019): 186-200. DOI: 10.31080/ASNH.2019.03.0308.

55. Raimi Morufu Olalekan, Bilewu Olaolu Oyinlola, Adio Zulkarnaini Olalekan, Abdulrahman Halimat (2019) Women Contributions to Sustainable Environments in Nigeria. Journal of Scientific Research in Allied Sciences. 5(4), 35-51. ISSN NO. 2455-5800. DOI No. 10.26838/JUSRES.2019.5.4.104.

56. Raimi M O, Suleiman R M, Odipe O E, Salami J T, Oshatunberu M, et al (2019). Women Role in Environmental Conservation and Development in Nigeria. Ecology \& Conservation Science, 1(2): DOI: 10.19080/ECOA.2019.01. Volume 1 Issue 2 - July 2019.

https://juniperpublishers.com/ecoa/pdf/ECOA.MS.ID.555558.pdf

57. Ajayi Folajimi Ajibola, Raimi Morufu Olalekan, Steve-Awogbami Oluseyi Catherine, Adeniji Anthony Olusola, Adebayo Patrick Adekunle (2020) Policy Responses to Addressing the Issues of Environmental Health Impacts of Charcoal Factory in Nigeria: Necessity Today; Essentiality Tomorrow. Communication, Society and Media. Vol 3, No 3. DOI: https://doi.org/10.22158/csm.v3n3p1. http://www.scholink.org/ojs/index.php/csm/article/view/2940.

58. Brownson RC, Baker EA, Leet TL, et al (2003). Evidence-Based Public Health. New York: Oxford University Press.

59. Pawson R, Greenhalgh T, Harvey G, et al (2005). Realist review - a new method of systematic review designed for complex policy interventions. J Health Serv Res Policy, 10(Suppl 1): $21-34$.

60. Morufu Raimi, Timothy Kayode Samson, Ajayi Bankole Sunday et al (2021). Air of Uncertainty from pollution profiteers: Status of ambient air quality of sawmill industry in Ilorin Metropolis, Kwara State, Nigeria, 25 February 2021, PREPRINT (Version 1) available at Research Square [https://doi.org/10.21203/rs.3.rs-270757/v1]

61. Raimi Morufu Olalekan, Adio Zulkarnaini Olalekan, Odipe Oluwaseun Emmanuel, Timothy Kayode Samson, Ajayi Bankole Sunday \& Ogunleye Temitope Jide (2020) Impact of Sawmill Industry on Ambient Air Quality: A Case Study of Ilorin Metropolis, Kwara State, Nigeria. Energy and Earth Science 3, No. 1, 2020. URL: http://dx.doi.org/10.22158/ees.v3n1p1. www.scholink.org/ojs/index.php/ees ISSN 2578-1359 (Print) ISSN 2578-1367 (Online)

62. Black BL, Cowens-Alvarado R, Gershman S, et al. (2005) Using data to motivate action: the need for high quality, an effective presentation, and an action context for decision-making. Cancer Causes Control; (16 Suppl 1): $15-25$.

63. Kerner J, Rimer B, Emmons K (2005). Introduction to the special section on dissemination: dissemination research and research dissemination: how can we close the gap? Health Psychol; 24 (5): $443-446$.

64. Raimi Morufu Olalekan, Adio Zulkarnaini Olalekan, Odipe Oluwaseun Emmanuel, Timothy Kayode Samson, Ajayi Bankole Sunday \& Ogunleye Temitope Jide (2020) Impact of Sawmill Industry on 
Ambient Air Quality: A Case Study of Ilorin Metropolis, Kwara State, Nigeria. Energy and Earth Science 3, No. 1, 2020. URL: http://dx.doi.org/10.22158/ees.v3n1p1.

www.scholink.org/ojs/index.php/ees ISSN 2578-1359 (Print) ISSN 2578-1367 (Online)

65. Olalekan RM, Adedoyin OO, Ayibatonbira A, et al (2019). “Digging deeper” evidence on water crisis and its solution in Nigeria for Bayelsa state: a study of current scenario. International Journal of Hydrology. 2019;3(4):244-257. DOI: 10.15406/ijh.2019.03.00187.

66. Raimi Morufu Olalekan, Omidiji Adedoyin O, Adeolu Timothy Adedotun, Odipe Oluwaseun Emmanuel and Babatunde Anu (2019) An Analysis of Bayelsa State Water Challenges on the Rise and Its Possible Solutions. Acta Scientific Agriculture 8 (2019): 110-125. DOI: 10.31080/ASAG.2019.03.0572.

67. Green LW, Mercer SL. (2001) Can public health researchers and agencies reconcile the push from funding bodies and the pull from communities? Am J Public Health; 91 (12): 1926 - 1929.

68. Thacker SB, Stroup DF (2006). Public health surveillance. In: Brownson RC, Petitti DB, eds. Applied Epidemiology: Theory to Practice. 2nd ed. New York, NY: Oxford University Press; 30 - 67.

69. Hutchison BG (1993). Critical appraisal of review articles. Can Fam Physician. 1993; 39 : 1097 1102.

70. Milne R, Chambers L (1993). Assessing the scientific quality of review articles. J Epidemiol Commun Health. 47 (3): $169-170$.

71. Oxman AD, Guyatt GH (1993). The science of reviewing research. Ann N Y Acad Sci. $703: 125$ - 133; discussion 133-124.

72. Zaza S, Briss PA, Harris KW (2005) The Guide to Community Preventive Services: What Works to Promote Health? New York: Oxford University Press.

73. Mullen PD, Ramirez G (2006). The promise and pitfalls of systematic reviews. Annu Rev Public Health. 27: $81-102$.

74. Waters E, Doyle J (2002). Evidence-based public health practice: improving the quality and quantity of the evidence. J Public Health Med. 24 (3): 227 - 229.

75. Gold MR, Siegel JE, Russell LB, et al. (1996) Cost-Effectiveness in Health and Medicine. New York: Oxford University Press.

76. Carande-Kulis VG, Maciosek MV, Briss PA, et al. (2000) Methods for systematic reviews of economic evaluations for the Guide to Community Preventive Services. Task Force on Community Preventive Services. Am J Prev Med. 18 (1 Suppl): 75 - 91.

77. Okoyen E, Raimi M O, Omidiji A O, Ebuete A W (2020). Governing the Environmental Impact of Dredging: Consequences for Marine Biodiversity in the Niger Delta Region of Nigeria. Insights Mining Science and technology 2020; 2(3): 555586. DOI: 10.19080/IMST.2020.02.555586. https://juniperpublishers.com/imst/pdf/IMST.MS.ID.555586.pdf.

78. http://www.countyhealthrankings.org/our-approach (accessed July 18, 2017). 
79. Cargo M, Mercer SL (2008). The value and challenges of participatory research: Strengthening its practice. Annu Rev Public Health. 29: 325 - 350.

80. Leung MW, Yen IH, Minkler M (2004). Community based participatory research: a promising approach for increasing epidemiology's relevance in the 21st century. Int J Epidemiol. 33 (3): 499 506.

81. Soriano FI (1995). Conducting Needs Assessments. A Multidisciplinary Approach. Thousand Oaks, CA: Sage Publications.

82. Sederburg WA (1992). Perspectives of the legislator: allocating resources. MMWR Morb Mortal Wkly Rep. 41 (Suppl): 37 - 48.

83. Hallfors $\mathrm{D}$, Cho H, Livert $\mathrm{D}$, et al. (2002) Fighting back against substance abuse: are community coalitions winning? Am J Prev Med. 23 (4): 237 - 245.

84. Turnock BJ (2004). Public Health: What It Is and How It Works. 3rd ed. Gaithersburg, MD: Aspen Publishers.

85. Brownson RC, Ballew P, Brown KL, et al. (2007) The effect of disseminating evidence-based interventions that promote physical activity to health departments. Am J Public Health. 97 (10): 1900 $-1907$.

86. Dreisinger M, Leet TL, Baker EA, et al. (2008) Improving the public health workforce: evaluation of a training course to enhance evidence-based decision making. J Public Health Manag Pract. 14 (2): $138-143$.

87. Brownson RC, Diem G, Grabauskas V, et al. (2007) Training practitioners in evidence-based chronic disease prevention for global health. Promot Educ. 14 (3): 159 - 163.

88. Gebbie K, Merrill J, Hwang I, et al. (2002) Identifying individual competency in emerging areas of practice: an applied approach. Qual Health Res. 12 (7): 990 - 999.

89. Birkhead GS, Davies J, Miner K, et al. (2008) Developing competencies for applied epidemiology: from process to product. Public Health Rep. 2008; 123 (Suppl 1): 67 - 118.

90. Brownson R, Ballew P, Kittur N, et al. (2009) Developing competencies for training practitioners in evidence-based cancer control. J Cancer Educ. 24 (3): 186 - 193.

91. Baker EA, Brownson RC, Dreisinger M, et al. (2009) Examining the role of training in evidence-based public health: a qualitative study. Health Promot Pract. 10 (3): $342-348$.

92. Maxwell ML, Adily A, Ward JE. (2007) Promoting evidence-based practice in population health at the local level: a case study in workforce capacity development. Aust Health Rev. 31 (3): 422 - 429.

93. Maylahn C, Bohn C, Hammer M, et al. (2008) Strengthening epidemiologic competencies among local health professionals in New York: teaching evidence-based public health. Public Health Rep. 123 (Suppl 1): 35 - 43.

94. Linkov F, LaPorte R, Lovalekar M, et al. (2005) Web quality control for lectures: Super course and Amazon.com. Croat Med J. 46 (6): 875 - 878. 
95. Proctor EK. (2004) Leverage points for the implementation of evidence-based practice. Brief Treatment Crisis Intervent. 4 (3): 227 - 242.

96. Chambers LW (1992). The new public health: do local public health agencies need a booster (or organizational "fix") to combat the diseases of disarray? Can J Public Health. 83 (5): 326 - 328.

97. Bryan RL, Kreuter MW, Brownson RC. (2008) Integrating Adult Learning Principles into Training for Public Health Practice. Health Promot Pract. Apr 2.

98. Wright K, Rowitz L, Merkle A, et al. (2000) Competency development in public health leadership. Am J Public Health. 90 (8): 1202 - 1207.

99. Goodman RM, Wheeler FC, Lee PR (1995). Evaluation of the Heart to Heart Project: lessons from a community-based chronic disease prevention project. Am J Health Promot; 9: 443 - 455.

100. Odubo Tonbra Robert and Raimi Morufu Olalekan (2019) Resettlement and Readjustment Patterns of Rural Dwellers During and After Flood Disasters in Bayelsa State Nigeria. British Journal of Environmental Sciences Vol .7, No .3, Pp. 45-52, July 2019. eajournals.org.

101. Wolff, T. J. (2001). Special section: Contemporary issues series I community coalition buildingContemporary practice and research. American Journal of Community Psychology, 29.

102. http://www.nlm.nih.gov.

103. Ginter PM, Duncan WJ, Capper SA. (1992) Keeping strategic thinking in strategic planning: macroenvironmental analysis in a state health department of public health. Public Health. 106: $253-269$.

104. Florin P, Stevenson J. (1993) Identifying training and technical assistance needs in community coalitions: a developmental approach. Health Educ Res. 8: 417 - 432.

105. Kahn EB, Ramsey LT, Brownson RC, et al. (2002) The effectiveness of interventions to increase physical activity. A systematic review (1,2). Am J Prev Med. 22 (4 Suppl 1): 73 - 107.

106. Jacobs J, Dodson E, Baker E, et al. (2010) Barriers to evidence-based decision making in public health: a national survey of chronic disease practitioners. Public Health Rep.

107. Savitz DA. (2003) Interpreting Epidemiologic Evidence. Strategies for Study Design and Analysis. New York, NY: Oxford University Press.

108. Anderson LM, Brownson RC, Fullilove MT, et al. (2005) Evidence-based public health policy and practice: promises and limits. Am J Prev Med; 28 (5 Suppl): 226 - 230.

109. https://www.bessi-collab.net/

\section{Figures}


- Scientific literature in systematic reviews

- Scientific literature in one or more journal articles

- Public health surveillance data

- Program evaluations

- Qualitative data

- Community members

- Other stakeholders

- Media/marketing data

- Word of mouth

- Personal experience

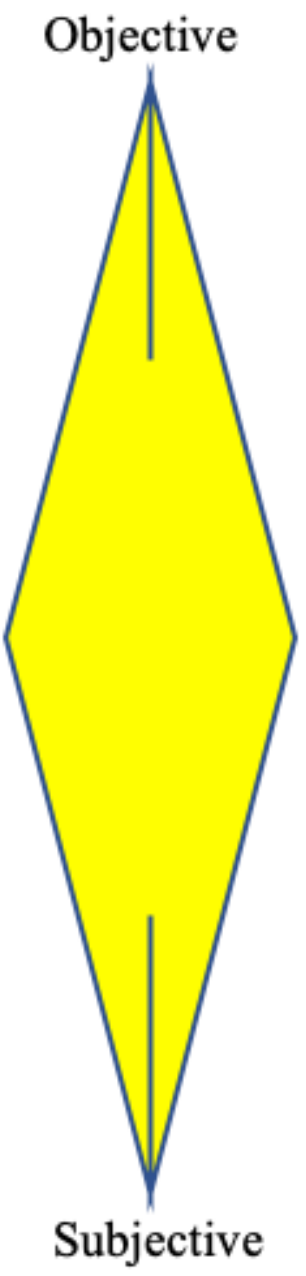

Figure 1. Different forms of evidence.

Source: Adapted from Chambers and Kerner [27] and Raimi et al., [2]

Figure 1

Different forms of evidence. 


\section{Aggregate Health Benefits}

Quadrant IV

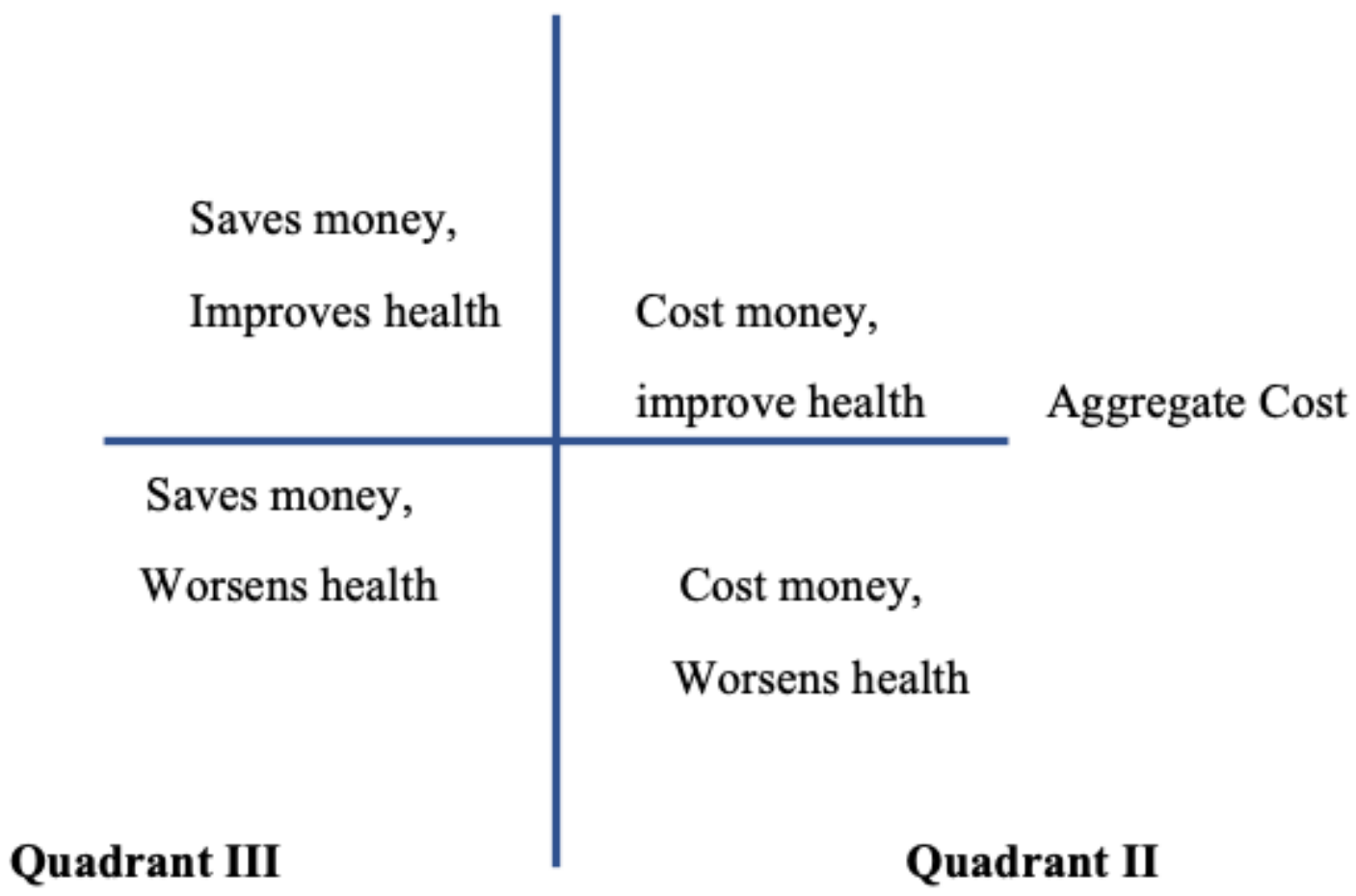

Figure 2: Possible Outcomes of an economic evaluation

Adapted from Raimi et al., [2]

Figure 2

Possible Outcomes of an economic evaluation 


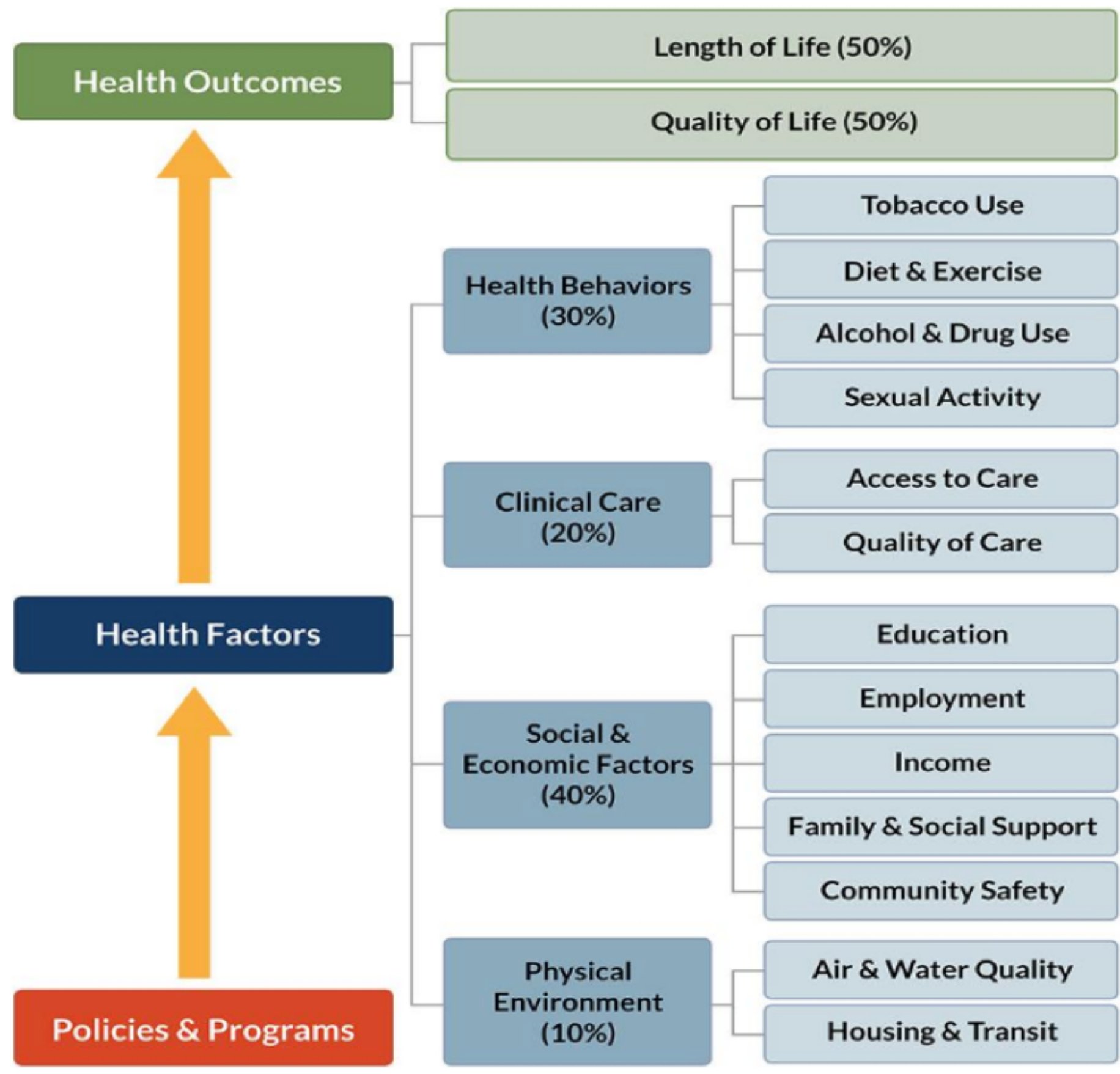

County Health Rankings model $\odot 2016$ UWPHI

Figure 3

County Health Rankings \& Roadmaps | Source: Reprinted with permission from County Health Rankings \& Roadmaps, [78] 


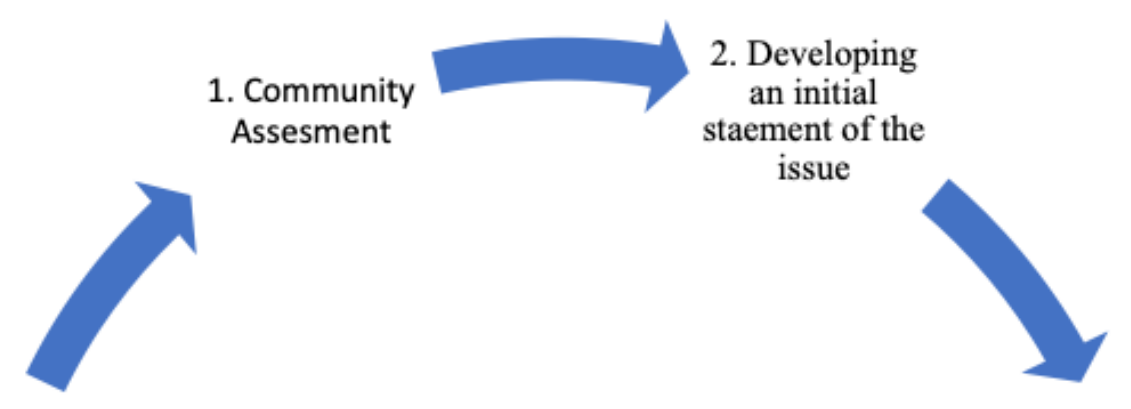

7. Evaluating the program or policy

\section{Quantifying} the issue

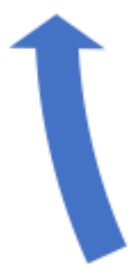

6. Developing an action plan and implementing intervention

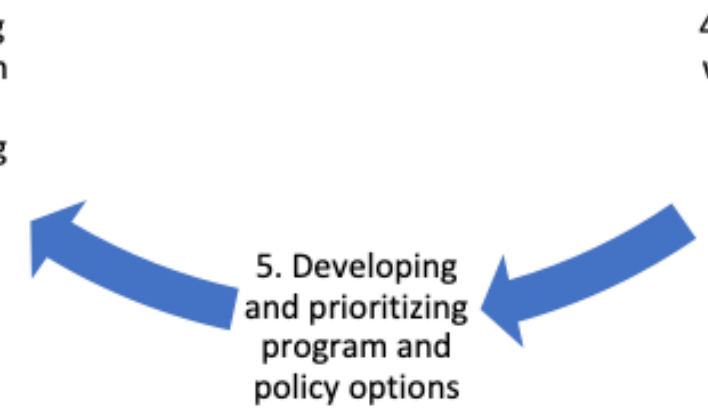

4. Determining what is known through the scientific literature

\section{Figure 4}

Training Approach for evidence-based Environmental/Public Health Adapted from Brownson et al., [58]; Hallfors et al., [83] 
Health Organization, National \& Local Governments, Community Organizations \& Leaders, Industry, Development Partners (NGOs)

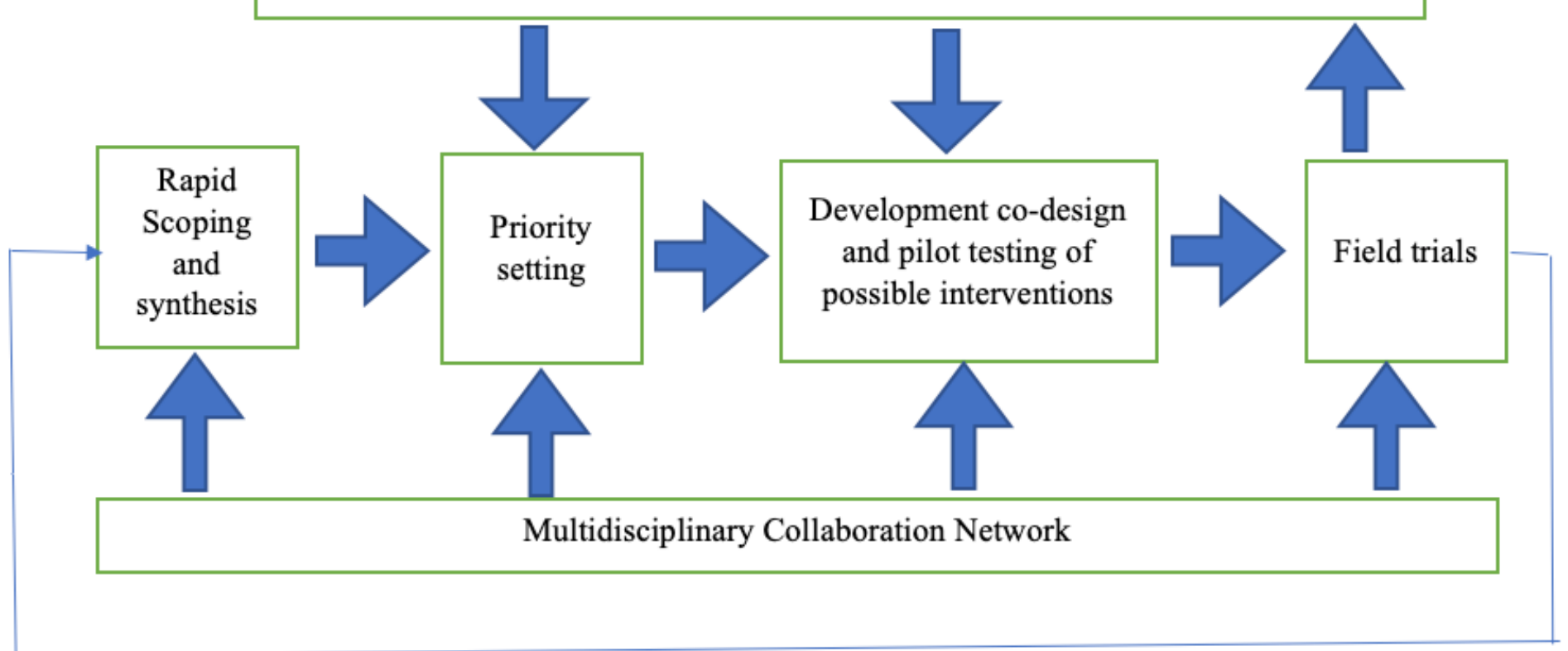

\section{Figure 5}

Behavioral Environmental Social and System Intervention (BESSI) (For Pandemic Preparedness) Research Strategy 